\title{
Intellectual Property, Tariffs, and International Trade Dynamics
}

\author{
Federico Mandelman and Andrea Waddle
}

\section{Working Paper 2019-10 April 2019}

\begin{abstract}
The emergence of global value chains not only leads to a magnification of trade in intermediate inputs but also to an extensive technology diffusion among the different production units involved in arms-length relationships. In this context, the lack of enforcement of intellectual property rights has recently become a highly controversial subject of debate in the context of the China-U.S. trade negotiations. This paper analyzes the strategic interaction of tariff policies and the enforcement of intellectual property rights within a quantitative general equilibrium framework. Results indicate that, in principle, tariffs could be an effective deterrent for weak protections for intellectual property. Moreover, weakening enforcement may be a strong deterrent for raising tariffs. These results combined indicate that there is scope for international cooperation on these fronts.
\end{abstract}

JEL classification: F41, F42, F51, F21, F13

Key words: tariffs, intellectual property rights, technology capital transfers, international trade

https://doi.org/10.29338/wp2019-10

This paper was written in preparation for the Carnegie-Rochester-NYU Conference on Public Policy. The authors thank seminar participants at the Bureau of Economic Analysis, the University of Virginia, and the Federal Reserve Bank of Atlanta for useful comments. The views expressed here are those of the authors and not necessarily those of the Federal Reserve Bank of Atlanta or the Federal Reserve System. Any remaining errors are the authors' responsibility.

Please address questions regarding content to Federico Mandelman, Federal Reserve Bank of Atlanta-Research Department, 1000 Peachtree Street NE, Atlanta, Georgia, 30309-4470, federico.mandelman@atl.frb.org, or Andrea Waddle, University of Richmond, Robins School of Business, 28 Westhampton Way, Richmond, VA 23173, awaddle@richmond.edu.

Federal Reserve Bank of Atlanta working papers, including revised versions, are available on the Atlanta Fed's website at www.frbatlanta.org. Click "Publications" and then "Working Papers." To receive e-mail notifications about new papers, use frbatlanta.org/forms/subscribe. 


\section{Introduction}

In the wake of the 2008 financial crisis and the Great Recession, the world has seen a resurgence of protectionist policies. The Trump administration has pursued policies that aim to reduce imports into the United States and to use tariffs as a bargaining chip to protect U.S. intellectual property. In particular, the administration has sought to "punish" Chinese firms and the Chinese government for appropriation of American intellectual property through increasing tariffs in a retaliatory way. In the context of these developments, several questions naturally arise. First, to what extent are trade and intellectual property protections related and how? Second, how do policies governing the enforcement of intellectual property rights interact with trade policy? Third, how might we measure the effects of these policies on the welfare of citizens in each country and on the development of intellectual property?

Although there is a large literature on both the diffusion of technology across borders and on the causes and effects of international trade, to our knowledge, there is no unified framework in which to study the interaction between these two important forces. In this paper, we fill the gap in the literature by merging two strands of research: the one that studies international trade and the one that studies intellectual property creation, diffusion, and appropriation. Our approach allows us to address the questions above within a unified framework which lets us to explore the interaction between two different types of policy levers: protection of intellectual property rights and tariffs.

There is an existing empirical literature that shows that intellectual property is transferred between countries within the boundaries of multinational enterprises (MNEs). Moreover, this transfer is more likely to occur when the recipient country has strong protections for intellectual property (see for example Branstetter et al 2006). We add to this empirical literature by providing suggestive evidence that technology transfer occurs between multinationals and unaffiliated parties and that this transfer is tied to vertically integrated supply chains between the multinationals and the suppliers of intermediate goods. We use data from the Bureau of Economic Analysis on the activities of U.S. multinationals to show that those multinationals that import more from unaffiliated parties also receive more royalties (payments for technology transfer) 
from unaffiliated parties than their counterparts that do not engage in this sort of trade. We use this empirical evidence to guide our modeling choices.

We then build a model which provides a unified framework in which to explore the interplay between international trade and technology capital. On the trade side, we build on Ghironi and Melitz (2005), which proposes a dynamic extension of the Melitz (2003) model with monopolistic competition and heterogeneous firms. We modify their model by incorporating international transfer of technology capital. The model draws heavily upon McGrattan and Prescott (2009, 2010) and, in particular on Holmes et al (2015), which develops a model of foreign direct investment aimed at quantifying the effect of the requirement of technology capital transfer in order to gain market access, known as quid pro quo policies, imposed by China on international investors. We model technology capital in the same way as Holmes et al (2015), and assume it is non-rival intangible capital that can be used across locations. Examples of this technology capital include accumulated know-how obtained from investments in R\&D, patents, and blueprints. We include two policy levers in the model: tariffs and enforcement of intellectual property rights and we allow for interaction between these two policies.

In the model, entrepreneurs in a more developed country invest in a stock of non-rival technology capital. In order to start operating, entering goods producing firms must rent or license this technology capital. One may think of this as firms needing blueprints in order to know how to produce. The non-rival nature of this technology capital means that the return to investing it is increasing in the number of firms that license it. ${ }^{1}$

Heterogenous goods producing firms exist in both the more developed (Home) and the less developed (Foreign) country. By assumption, Foreign cannot produce its own technology capital but it may appropriate it in order to produce goods without directly paying for technology capital, as there is less than perfect enforcement of intellectual property rights within the foreign country. The main trade-off faced by entrepreneurs, therefore, is the desire to increase the return to their non-rival technology capital by renting it in multiple countries but knowing that renting it out in countries with weak enforcement of intellectual property rights may result in appropriation. The main trade-off faced by the agents in Foreign is that appropriating technology capital

\footnotetext{
${ }^{1}$ See McGrattan and Prescott (2010) for a nice discussion of this.
} 
reduces the cost of production but goods made with appropriated technology capital cannot be traded internationally, so paying licensing fees gives these firms access to the international market. Most importantly, technology capital must be legally licensed first, before being subject of possible appropriation. ${ }^{2}$ There is scope, therefore, for the two policy levers that we include to have an impact on firm decisions.

We conduct a number of experiments to explore model dynamics. We first show that an increase of home tariffs on foreign goods reduces international trade. Exports and imports fall simultaneously and firm profits fall across the board, lowering output in both countries. However, the foreign country bears the brunt of this policy action. Tariffs directly lower demand for foreign products, resulting in depreciation of the real exchange rate in Foreign. In contrast, the imposition of tariffs is welfare improving in Home. Home consumers benefit not only from a real exchange rate appreciation that lowers the relative price of imported goods, but also from tariff revenues that are rebated back to them as a lump-sum. Most importantly, home entrepreneurs obtain more royalties when tariffs increase. The intuition is as follows. In Foreign, more expensive imported goods from Home - due to the real currency depreciation - encourages substitution away from imported goods. This action induces more firm entry in Foreign, leading to a greater technology transfer from Home and, therefore, an increase in royalties.

We then allow for a tit-for-tat tariff escalation in which an increase in tariffs is reciprocated by an identical move by the partner country. This ultimately leads to a full-blown trade war with very high tariffs. We show that even if Foreign ends up increasing tariffs by more than Home, retaliation serves to punish Foreign much more than it punishes Home. By sharply slashing imports, foreign consumers face a greatly reduced access to consumption goods produced by home firms that are far more efficient. Instead, they are forced to largely rely on less-productive local producers as a result. ${ }^{3}$

A tariff retaliation by Foreign maybe ineffective; however, Foreign can obtain different results by weakening the enforcement of intellectual property rights of home entrepreneurs within its

\footnotetext{
${ }^{2}$ As an example, Siemens had a joint venture with China National Rail (CNR) that completed Chinas first highspeed rail line in 2008. The next line was built by CNR, with only a minor role for Siemens. See Holmes et al (2015) for details.

${ }^{3}$ To illustrate this with a simple example, consider China's reliance on imported computers chips from the US, which makes it vulnerable in a trade war (see Financial Times December 8, 2018).
} 
borders. This policy move induces home entrepreneurs to license less of their technology capital to Foreign, meaning that fewer licensed firms operate in Foreign. In turn, foreign appropriators more freely seize the existing stock of home technology deployed in Foreign. This boosts the production of counterfeited goods, thus eating market share from licensed producers that are both established in Foreign and are exporting from Home. In Home, entrepreneurs will receive fewer royalties from licensed firms; in Foreign, the appropriators greatly increase their profits and their employees see their wages increase.

By weakening the enforcement of intellectual capital enough, the foreign country may fully reverse the welfare results arising from an increase in home tariffs: welfare increases in Foreign and falls in Home. Put it differently, beggar-thy-neighbour becomes beggar-thyself after this alternative type of retaliation.

We then explore the reverse scenario where Foreign increases its appropriation of home technology capital and Home retaliates by increasing tariffs. If Foreign appropriates technology without retaliation, it improves its welfare stance at the cost of the welfare of Home. However, in this case, Home is able to retaliate effectively with a decisive increase in tariffs. Together, these results imply that there is scope for cooperation. It is important to note that we do not conduct optimal policy analysis. However, our environment resembles an infinitely repeated prisoners' dilemma in which the threat of an effective retaliatory grim trigger strategy supports cooperation in equilibrium.

\section{Related Literature}

To the best of our knowledge, ours is the first paper to study the interaction between international trade and the appropriation of intellectual property rights (IPR) by foreign entities. On the policy front, this paper shows how retaliatory tariffs interact with changes to the IPR legal framework to jointly characterize the dynamics of trade and R\&D. The structural approach also allows for welfare analysis of the alternative policy specifications.

This paper is related to several strands of research. We combine two important frameworks: 
Ghironi and Melitz (2005), ${ }^{4}$ which builds a dynamic model of international trade, and Holmes et al (2015), which models international technology flows across countries within multinational enterprises. Ghironi and Melitz (2005) is a dynamic, stochastic two-country trade model that extends the workhorse Melitz (2003) model by allowing for macroeconomic dynamics through the inclusion of household saving which funds costly firm creation. We build upon this framework by incorporating technology capital, which was first introduced by McGrattan and Prescott (2009) and was further developed in Holmes et al (2015). Instead of household saving directly funding the creation of new firms as in Ghironi and Melitz (2005), we allow it to fund entrepreneurial investment in technology capital. As in Holmes et at (2015), this technology capital is non-rivalrous in nature and may be appropriated if deployed to countries with weak intellectual property rights (IPR). We innovate on the set-up in Holmes et al (2015) by allowing for technology capital to be rented to arms-length parties, as in Waddle (2018), which allows us to explore the more general case of supply chain integration, whether that integration occurs via ownership of foreign subsidiaries or via supply chain agreements between arms-length parties.

We contribute to a growing literature which focuses on the impact that trade policy has on aggregate variables in a dynamic setting. In a recent paper, Akcigit et al (2018) build a model with a dynamic link between trade and a firm's innovation decisions and use it to study the optimal policy mix for a government which wants to support domestic firms in global competition and has at its disposal tariff policies and R\&D subsidies. They find that unilaterally increasing import tariffs can generate short-run gains for domestic producers, but in the long-run, this policy decreases innovation and thereby leads to lower welfare. Along these same lines, Coelli et al (2016) study the impact that the trade liberalizations that occurred in the 1990s had upon innovation, as measured patenting activity and find that these liberalizations encouraged innovation. Moxnes et al (2012) focuses on imports of intermediates and the complementary relationship between importing intermediates and innovation at the firm-level. They find that innovation and import activity are closely linked and that almost all innovators are importers of intermediates. We add to this literature by exploring the interaction between trade policy and IPR protection in the context of global supply chains. Barbiero et al (2017), Barattieri et al (2018), Erceg et al

\footnotetext{
${ }^{4}$ Alessandria and Choi (2007) present a very similar framework.
} 
(2017), Farhi et al (2014), and Linde and Pescatori (2017) are some notable examples that explore the effect of trade policy instruments on macroeconomic dynamics, though none focus directly on innovation.

Also related is the literature that explores international technology diffusion through trade, as well as spillovers to the local economy. A number of studies, including Acharya and Keller (2009), Caselli and Coleman (2001) and Xu and Wang (2001), explore the role that international trade in intermediates, capital, and embodied technology play in international technological diffusion. Jiang et al (2018) study the case of technology transfer to China within joint ventures and the impact that this has on domestic technology in China through spillovers. Holmes et al (2015) has a similar flavor, but focuses on the idea that technology might be appropriated by Chinese firms for use outside of the joint venture. Perla et al (2015) build on this evidence by showing that trade liberalization increases the spread in profits through increased export opportunities and foreign competition, which induces more rapid technology adoption. We draw upon these studies and consider a framework where expropriation is one of the explicit costs faced by the producers of technology capital if they choose to rent it to intermediate goods producers in countries with weak IPR protection. Furthermore, in our model, foreign firms can avoid trade barriers by transferring technology to foreign arms-length parties. This idea closely relates to the existing literature that studies the phenomenon of Tariff-Jumping FDI in which foreign firms avoid tariffs by locating production within the destination market. Refer, for instance, to Blonigen (2004) and references therein for details.

We also contribute to the literature that explores the impact that intellectual property protection policy has upon trade and technology transfer. Lin and Lincoln (2017) show that there is a strong correlation between a firm holding a patent and that firm being an exporter. Moreover, firms who export do so more intensively to countries with stronger IPR. Lee and Mansfield (1996) show that weak patent protection and weak IPR discourage multinational expansion into a country. Smith (2001) shows that stronger patent rights are associated with more R\&D done for and by the affiliate. Branstetter et al (2006) show that technology transfer between multinational parent companies and their affiliates increases after there is a patent reform within a country, especially for those MNEs that use patents extensively. Bilir (2014) focuses on vertical integration, 
studying the trade-off between low production costs and possible appropriation of intellectual property in the form of product imitation faced by the MNE when choosing production locations. She finds that multinationals which produce products with shorter product lifecycles are less sensitive the IPR regimes when choosing production locations and that all multinationals are more likely to produce in low-cost locations with better intellectual property protection.

\section{Trade and Technology Transfer in the Data}

In this section, we provide suggestive evidence that technological transfer occurs through global supply chains, building on previous work that has linked supply chains to technological transfer. A number of studies have established that proprietary technology capital is transferred within multinationals, from parent to affiliate. We contribute to this literature by examining technology transfers through arms-length relationships. In particular, we are interested in technology transfer that occurs along vertically integrated supply chains. We examine industry-level data from the Bureau of Economic Analysis (BEA) Benchmark Surveys of US Direct Investment Abroad from 1999 and 2004. These survey report information on royalties received by parents from both their foreign affiliates and from unaffiliated parties. These royalty payments include payments for industrial products and processes, franchise fees, fees for the use of trademarks, and payments for other intangibles. Notably, the payments for industrial products and processes capture technology licensing fees and these fees account for the vast majority of the total royalty payments. $^{5}$

Following Branstetter et al (2006), we use these royalty payments as a proxy for technological transfer. We depart from their specification by examining royalty payments received by parents from unaffiliated parties, versus their focus on intra-firm royalty payments, as we are exploring whether these transfers occur across countries through arms-length relationships as well. ${ }^{6}$ They assert that multinationals are reluctant to transfer technology through non-ownership channels, a claim which they support with anecdotal evidence from Lee and Mansfield (1996). However,

\footnotetext{
${ }^{5}$ Technology licensing fees accounted for 88 percent of all royalty payments in 1989 (Branstetter et al, 2006).

${ }^{6}$ Branstetter et al (2006) establish that MNEs transfer technology from parent to affiliates and they do so more intensively when the affiliate is located in a country with strong IPR.
} 
in the survey years that we analyze, roughly 30 to 35 percent of all royalties received by US parents are paid by unaffiliated parties, indicating that technology is, indeed, transferred through arms-length channels. ${ }^{7}$ We focus on the royalties that are received from unaffiliated parties and examine the relationship between these royalty receipts and imports from unaffiliated parties. The data on royalties and imports from unaffiliated parties are publicly available at the industrylevel in benchmark years. In order to test the impact of imports on royalty receipts, we begin by estimating the following equation:

$$
\ln \left(\operatorname{Roy}_{i t}\right)=\beta_{0}+\beta_{1} \ln \left(\text { Imports }_{i t}\right)+\beta_{2} \text { Size }_{i t}+\gamma_{i}+T_{t}+\epsilon_{i t}
$$

where $R o y_{i t}$ is the royalties received by parents from unaffiliated parties in industry $i$ and year $t$, Imports ${ }_{i t}$ is the imports from unaffiliated parties, Size $_{i t}$ is the size of the industry in year $t$, which we measure either by sales by parents in the industry or employment by parents, and $\gamma_{i}$ and $T_{t}$ are industry and time-fixed fixed effects, respectively. It is important that we control for the industry size, as it has been established that larger industries tend to be more R\&D intensive, thus increasing the size of royalty receipts in those industries. As can be seen in Table 1, once we control for industry and time fixed effects, a one percent increase in imports from unaffiliated parties is associated with roughly a 1.4 percent increase in royalties received from unaffiliated parties. If we further control for the size of the industry in the United States, either using parent sales or parent employment, an increase imports from unaffiliated parties is associated with roughly a 1.05 percent increase in royalties received by the parent from unaffiliated parties. These estimates are statistically significant at the 5 and 10 percent levels, respectively.

One might be concerned that royalty received by the parent are not a good proxy for the transfer of technology. Branstetter et al (2006) have a nice discussion of why this variable does, in fact, measure the transfer of technology well. To summarize their argument, the existing tax code virtually ensures that royalty receipts are measuring payments for the transfer of technology and accurately reflect the value of this technology.

We take these results as evidence that technology transfer occurs through arms-length rela-

\footnotetext{
${ }^{7}$ It is likely that the technology that is being transferred is not the "crown jewels," but rather less advanced or less valuable technologies. We will account for this fact in the model.
} 
Table 1: Royalties and Trade

\begin{tabular}{|c|c|c|c|}
\hline Variable & $\begin{array}{c}(1) \\
\ln (\text { Royalties) } \\
\end{array}$ & $\begin{array}{c}(2) \\
\ln \text { (Royalties) }\end{array}$ & $\begin{array}{c}(3) \\
\ln \text { (Royalties) }\end{array}$ \\
\hline $\ln$ (Unaff Imports) & $\begin{array}{l}1.431^{* *} \\
(0.582)\end{array}$ & $\begin{array}{l}1.049^{*} \\
(0.548)\end{array}$ & $\begin{array}{l}1.054^{*} \\
(0.517)\end{array}$ \\
\hline $\ln ($ Parent Emp) & & $\begin{array}{c}2.545^{*} \\
(1.290)\end{array}$ & \\
\hline $\ln$ (Parent Sales) & & & $\begin{array}{l}2.559^{* *} \\
(1.129)\end{array}$ \\
\hline Observations & 47 & 47 & 47 \\
\hline R-squared & 0.764 & 0.899 & 0.908 \\
\hline
\end{tabular}

tionships between the developers of technology capital ${ }^{8}$ and foreign entities who seek to use it, in addition to occurring through the ownership channels explored in previous studies. We will focus on arms-length transactions in what follows, though it should be noted that one can conceptualize diffusion of technology capital within a multinational as a special case of our model environment.

\section{Model}

The model environment consists of two countries: Home and Foreign. They differ in their productivity, ability to produce technology capital, and protection of intellectual property. Home is assumed to be relatively more developed, meaning that it is more productive and it is capable of creating new technology capital. It consists of two types of representative agents - entrepreneurs that produce technology capital and households that supply labor to produce goods and own the goods producing firms. Furthermore, Home has perfect enforcement of intellectual property rights, meaning that intellectual property is not subject to appropriation. The foreign country, on the other hand, is not able to produce technology capital and therefore only consists of a single type of representative households which supplies labor in order to produce goods. These

\footnotetext{
${ }^{8}$ Multinational Enterprises are responsible for roughly 90 percent of all research and development spending that occurs in the United States.
} 
households also own two types of goods-producing firms, which we will describe in more detail below. The foreign country is assumed to have less than perfect protection of intellectual property rights and, therefore, technology capital that is used in the foreign country may be subject to appropriation. In both countries, firms produce heterogeneous consumption goods under monopolistic competition.

All new firms (start-ups) require technology capital to enter the market and start producing. ${ }^{9}$ This technology capital may be interpreted as the stock of patents, technological know-how, or brands. The prospective entrants license technology capital from the entrepreneurs before entering the market place and pay royalty payments to the entrepreneurs in exchange for the use of their technology capital. From the firms' perspective, these royalty payments constitute an irreversible sunk-cost investment that they incur only once. ${ }^{10}$ Upon payment for the use of technology capital, each firm receives a productivity draw and discovers how productive it will be. Firms then may receive an exogenous exit shock, so some new firms may never produce. Production occurs after entry and exit. As in the Melitz framework, there is a fixed cost which firms must pay in order to export. Therefore, only the most productive firms will be able to afford to pay this cost and export to the foreign economy.

Intangible technology capital is non-rival and home entrepreneurs can rent it to prospective firm entrants in both the home and the foreign economies. In this case that entrepreneurs chooses to rent technology capital to foreign firms, however, they face a trade-off. By licensing their non-rival technology capital to more users, they are able to increase the returns to investing in it. However, the institutional setting in the foreign country is lax in enforcing the property rights of the home entrepreneurs and so their intellectual property may be appropriated. To account for potential appropriation of technology capital, we assume that the foreign representative household jointly owns what we will call licensed and appropriating firms. Licensed firms in Foreign closely resemble the firms in Home: they rent the technology capital from the home entrepreneurs to start operating, are monopolistically competitive, and those firms that are most

\footnotetext{
${ }^{9}$ One may think of this as firms needing blueprints in order to know how to produce.

${ }^{10}$ In the data, licensing fees and royalties take many forms. For simplicity, we will focus on agreements in which the firm that is receiving the technology capital pays a one-time licensing fee to the creator of that technology capital for its use.
} 
productive will export to Home. Foreign appropriators will use the appropriated technology from the home entrepreneurs to replicate the goods that both home and foreign licensed firms produce. However, appropriators will be less efficient in producing with the appropriated technology than those that license it. This can be reinterpreted as consumers heavily discounting the utility they get from goods they regard as counterfeit. Following the evidence in Holmes et al (2015), we will assume that appropriated property rights "stop at the border." In our model, this implies that goods produced by the appropriators can only be sold within the boundaries of the foreign economy. In principle, our setup could be modified to merge home households and entrepreneurs into a single representative household that owns "multinationals" that jointly produce goods and invest in $R \& D$, brands, and other intangibles. Those multinationals could export their goods to the foreign economy, as well as license their intellectual property to unaffiliated parties through arms-length transactions. The choice of of two separate agents is made for analytical convenience.

Finally, we close the model with two planners that will be responsible for the implementation of alternative policy arrangements in each of their countries. We will consider two policy instruments: tariffs and intellectual property protection. Each planner may modify the tariffs on imported goods. In addition, the foreign planner will be able to improve (or worsen) the regulatory framework that dictates the protection of intellectual property rights. We will also allow for interaction between these two policy levers. Namely, the home economy may respond to changes in the enforcement of intellectual property in the foreign economy with a change in tariffs. Similarly, the foreign country may strengthen or weaken enforcement of intellectual property rights in response to the imposition of higher tariffs by the home planner.

\subsection{Home}

\subsubsection{Consumption Preferences}

Entrepreneurs and Households share the same preferences over a continuum, $\Omega$, of heterogeneous consumption goods, $\omega: C_{t}=\left(\int_{\omega \in \Omega_{t}} c_{t}(\omega)^{(\theta-1) / \theta} d \omega\right)^{\theta /(\theta-1)}$, were $\theta>1$ is the elasticity of substitution across goods. Aggregate consumption of the home country, denoted by $C_{t}$, is 
the sum of the consumption of the households, $C_{h, t}$, and of the entrepreneurs, $C_{e, t}$, and may therefore be expressed $C_{t}=C_{h, t}+C_{e, t}$. Each firm in Home or in Foreign produce one a single variety, $\omega$, of consumption goods which can be consumed domestically or exported. Firm entry and exit in Home and Foreign will determine how many varieties are available for consumption in any given period of time $t: \Omega_{t} \subset \Omega$. Consumption of each variety $\omega$ is denoted as $c_{t}(\omega)$, and its price, $p_{t}(\omega)$, is expressed in domestic currency. ${ }^{11}$ The consumption-based price index, CPI, for Home is $P_{t}=\left(\int_{\omega \in \Omega_{t}} p_{t}(\omega)^{1-\theta} d \omega\right)^{1 /(\theta-1)}$, and the resulting demand for each variety $\omega$ is $c_{t}(\omega)=\left(p_{t}(\omega) / P_{t}\right)^{-\theta} C_{t}$. Hereafter, home variables will be expressed in real terms, i.e. in units of the CPI.

\subsubsection{Entrepreneurs}

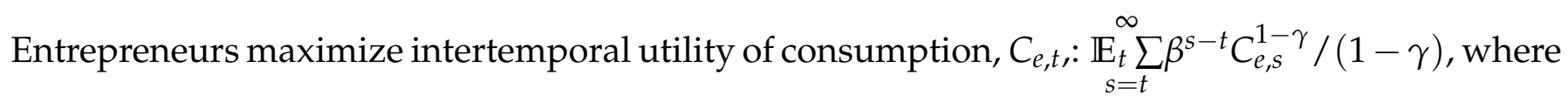
$\gamma$ is the elasticity of intertemporal substitution. They supply labor inelastically $\left(L_{e, t} \equiv L_{e} \equiv 1\right)$ to their own firms, so they do not receive a wage. They accumulate technology capital, $M_{t}$, which evolves as follows:

$$
M_{t}=X_{t}+\left(1-\delta_{M}\right) M_{t-1}
$$

where $X_{t}$ is the investment in new technology capital and $\delta_{M}$ is its capital depreciation.

To start operating, prospective firm entrants in Home, $N_{E, t}$, and Foreign, $N_{E, t}^{*}$, need to lease patents, license brands or rent the know-how from these technological entrepreneurs. Entrepreneurs' technology capital, $M_{t}$, is non-rival in nature and can be potentially rented to all firm entrants in Home and Foreign without being depleted. In exchange for this service, prospective home entrants pay royalties, $R_{t} M_{t-1}$, to entrepreneurs - where $R_{t}$ is the rental rate of technological capital. ${ }^{12}$ A similar contract is arranged with foreign start-ups. Royalties constitute a sunk entry costs that new firms incur only once. ${ }^{13}$

\footnotetext{
${ }^{11}$ Money is introduced solely as a convenient unit of account. Otherwise, it does not play any role in this flexible price setting.

${ }^{12}$ Note that $R_{t} M_{t-1} N_{e, t}$ is the expression for total royalties earned domestically. it.

${ }^{13}$ One may think of this as entrants purchasing a blueprint from the entrepreneur and paying a licensing fee for
} 
Deployment of Technology Capital in Foreign Given its non-rival nature, the same domestic investment in technology capital may be costlessly transferred to Foreign. However, entrepreneurs may choose to deploy less technology capital ${ }^{14}$ than they have available due to the presence of imperfect protection of intellectual property. In order to do so, they can choose to lower the intensity of deployment of their technology capital to Foreign, by only renting a fraction $q_{t}$ of the total stock of technology capital at any given time $t$. As in Holmes et al (2015), an entrepreneur that chooses to deploy technology capital in Foreign with an intensity $q_{t}$, will end up transferring $h\left(q_{t}\right) \in[0,1]$ units of its technology capital to the appropriators in Foreign.

This function $h($.$) is weakly increasing and weakly convex in q_{t}$ :

$$
h\left(q_{t}\right)=\Theta_{t}\left[q_{t} \exp \left(-\eta\left(1-q_{t}\right)\right)\right] ; \text { with } \eta>0
$$

This increasing functional form in square brackets follows Holmes et al (2015) and implies that the more technology capital is transferred, the greater the Foreign's appropriation of technology. Its convexity captures the idea that entrepreneurs might be willing to transfer small or less important ideas, while protecting the most important ones ${ }^{15}$ by only renting them in the home country. Notice that $h($.$) will be affected by exogenous changes in policy, which is characterized$ by $\Theta_{t}$, which we will describe in more detail in Section 3.3.

The evolution of technology capital deployed in Foreign, $M_{t}^{*}$, evolves as follows:

$$
M_{t}^{*}=X_{t}+\left(1-\delta_{M}\right)\left(1-h\left(q_{t}\right)\right) M_{t-1}^{*}
$$

Notably, domestic investment in technology, $X_{t}$, also serves to accumulate technology capital in Foreign. In turn, the last term accounts for capital depletion, which includes both depreciation, $\delta_{M}$, and the appropriated technology which is transfer to the foreign appropriators, $h\left(q_{t}\right)$.

Optimality Conditions In order to better understand the role that the non-rivalry of technology capital plays in the model, it is instructive to examine the problem that is being solved by

\footnotetext{
${ }^{14}$ Again, one can think of this as entrepreneurs selling fewer blueprints to foreign producers.

${ }^{15}$ These most important ideas are know as the crown jewels in the literature.
} 
entrepreneurs. Their sources of income include royalties received from entrants in both countries and lump-sum transfers of collected import duties (tariffs), $\Pi_{e, t}$, that are rebated back to them by the government. The sum of royalties paid by all $N_{E, t}$ entrants in the home country are equal to $R_{t} M_{t-1} N_{E, t}$. Given the choice of how intensively to deploy their technology capital abroad, $q_{t}$, the royalties received by entrepreneurs from foreign entrants equals $\mathbb{Q}_{t} R_{t}^{*}\left(q_{t} M_{t-1}^{*}\right) N_{E, t}^{*}$, where $\mathbb{Q}_{t}=\varepsilon_{t} P_{t}^{*} / P_{t}$ is the consumption-based real exchange rate and $\varepsilon_{t}$ is the nominal exchange rate. ${ }^{16}$ The per-period budget constraint may then be expressed as

$$
C_{e, t}+X_{t}=R_{t} M_{t-1} N_{E, t}+\mathbb{Q}_{t} R_{t}^{*}\left(q_{t} M_{t-1}^{*}\right) N_{E, t}^{*}+\Pi_{e, t}
$$

Entrepreneurs choose consumption, $C_{e, t}$, investment, $X_{t}$, and the intensity with which to deploy their technology to Foreign, $q_{t}$, in order to maximize their utility subject to the budget constraint, Equation (5), and the rules of motion for technology capital deployed in Home and Foreign, Equations (2) and (4), respectively. The solution to this maximization problem yields the following equilibrium conditions:

$$
\begin{aligned}
C_{e, t}^{-\gamma} & =\lambda_{t}+\lambda_{t}^{*} \\
\lambda_{t} & =\beta \mathbb{E}_{t}\left\{C_{e, t+1}^{-\gamma}\left(R_{t+1} N_{E, t+1}\right)+\lambda_{t+1}\left(1-\delta_{M}\right)\right\}, \\
\lambda_{t}^{*} & =\beta \mathbb{E}_{t}\left\{C_{e, t+1}^{-\gamma}\left(\mathbb{Q}_{t+1} q_{t+1} R_{t+1}^{*} N_{E, t+1}^{*}\right)+\lambda_{t+1}^{*}\left(1-\delta_{M}\right)\left(1-h\left(q_{t+1}\right)\right)\right\}, \\
C_{e, t}^{-\gamma}\left(\mathbb{Q}_{t} M_{t-1}^{*} R_{t}^{*} N_{E, t}^{*}\right) & =\lambda_{t}^{*}\left(1-\delta_{M}\right) h^{\prime}\left(q_{t}\right) M_{t-1}^{*}, \\
\text { with } h^{\prime}\left(q_{t}\right) & =\Theta_{t}\left(1+\eta q_{t}\right) \exp \left(-\eta\left(1-q_{t}\right)\right),
\end{aligned}
$$

where $\lambda_{t}$ and $\lambda_{t}^{*}$ are the multipliers associated to the the laws of motion for technology capital in Home and Foreign. Equations (7) and (8) are the Euler equations for the capital deployed in the home country and in the foreign country, respectively.

From Equation (6) we learn that when entrepreneurs sacrifice one unit of consumption today

\footnotetext{
${ }^{16}$ The consumption-based price index for Foreign is defined in the next section. $\mathbb{Q}_{t}$ is interpreted as units of home consumption per units of foreign consumption, while $\varepsilon_{t}$ is units of home currency per unit of foreign currency.
} 
for investment, they increase the stock of non-rival technology capital that will be deployed to both Home and Foreign. Notice that the pay-off to entrpreneurs is captured by $\lambda_{t}+\lambda_{t}^{*}$. Recall that because this stock of technology capital is non-rival, it can be costlessly deployed in both countries at the same time in the next period. The Euler equations (Equations 7 and 8) illustrate the payoffs that this extra unit of capital will yield: (discounted) royalties payments in $t+1$ plus the capital net of depreciation carried for the subsequent period. In particular, Equation (8) highlights the key trade-off faced by entrepreneurs in this framework: a higher transfer $q_{t+1}$ will increase royalties received by the entrepreneur but will decrease the stock of technology capital in the future given that agents in Foreign will appropriate some of the technology capital, represented by $1-h\left(q_{t+1}\right)$. Finally, Equation (9) illustrates the decision rule for $q_{t}$ given this intertemporal trade-off.

\subsubsection{Households in the Home Country}

The representative households solve a problem that is similiar to that of the entrepreneurs, max-

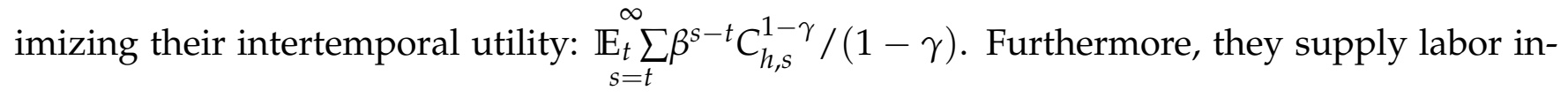
elastically $\left(L_{t} \equiv L \equiv 1\right)$ and receive a wage $w_{t}$ for their fixed amount of labor. They also hold shares of a fully diversified mutual fund which consists of ownership of all domestic firms that produce in period $t: N_{D, t}$. The number of existing firms is affected by entry and exit: new entrants, $N_{E, t}$, in period $t$ start producing (and paying dividends) in period $t+1$ and continue doing so until they are hit by an exit-inducing (bankruptcy) shock. The exit shock occurs with probability $\delta$ and affects existing incumbents and new entrants alike. ${ }^{17}$ The resulting law of motion for the number of firms is:

$$
N_{D, t}=(1-\delta)\left(N_{D, t-1}+N_{E, t-1}\right) .
$$

In period $t$, the mutual fund pays the average dividends paid by firms, $\tilde{d}_{t}$, multiplied by the number of home firms that produce in period $t$. Therefore, the households' total income from ownership of the mutual fund is equal to $\tilde{d}_{t} N_{D, t}$. Because the household wants a full diversified

\footnotetext{
${ }^{17}$ This implies that a proportion $\delta$ of new entrants will never produce.
} 
portfolio, the mutual fund administrator buys shares of all entering firms every period $N_{E, t} \tilde{v}_{t}$, where $\tilde{v}_{t}$ is the share (stock) value of an average firm. As shown later, the share value of the average entrant and existing incumbents is the same. The mutual fund administrator re-balances the portfolio each period to account for entry and exit; households repurchase their portfolio of surviving firms while shares of new firms are added to the existing portfolio and those of the exiting firms are written off. Given this, we can express the budget constraint of the representative household as:

$$
N_{E, t} \tilde{v}_{t}+C_{h, t}=w_{t} L+N_{D, t} \tilde{d}_{t}+\Pi_{h, t}
$$

where $\Pi_{h, t}$ are lump-sum transfers to the household from the government, which rebate the tariffs collected on imports from Foreign.

Households maximize utility subject to Equations (10) and (11). This maximization delivers a standard Euler equation for share holdings:

$$
\tilde{v}_{t}=\beta(1-\delta) \mathbb{E}_{t}\left[\left(\frac{C_{h, t+1}}{C_{h, t}}\right)^{-\gamma}\left(\tilde{d}_{t+1}+\tilde{v}_{t+1}\right)\right]
$$

Absent speculative bubbles, forward iteration of Equation (12) yields the asset pricing solution:

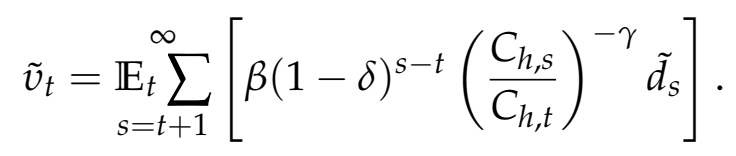

In equilibrium, the average firm value for, $\tilde{v}_{t}$, is the present discounted value of the expected stream of dividends, where the stochastic discount factor reflects the possibility of firm exit, $\delta$.

\subsubsection{Firms in the Home Country}

Prior to entry, individual firms are identical and face a sunk entry cost, $f_{E, t}$, which is equal to the royalties paid to the entrepreneurs for use of technology capital: $f_{E, t}=R_{t} M_{t-1} \cdot{ }^{18}$ Free-entry implies that entry occurs until the average firm value is equal to the sunk entry cost for each firm. Namely, the royalties paid must equal the average value of the firm: $\tilde{v}_{t}=f_{E, t}$. Upon entry, firms draw their firm-specific productivity level $\mathbf{z}$ from a common distribution $G(\mathbf{z})$ with

\footnotetext{
${ }^{18}$ Fixed costs are measured in units of effective labor: $f_{E, t}=f_{e} \frac{w_{t}}{Z_{t}}$.
} 
support $\left[\mathbf{z}_{\min }, \infty\right)$, which remains constant thereafter. Each firm produces a distinctive variety, $\omega$. Therefore, the idiosyncratic productivity $\mathbf{z}$ may also serve as an index for the specific variety produced by this firm.

Labor is the only factor of production. Each firm produces $Z_{t} \mathbf{z}$ units of output per unit of labor employed, where $Z_{t}$ is country-specific aggregate TFP , which is equivalent to labor productivity. Labor productivity is subject to exogenous time-varying shocks and may be expressed as $Z_{t}=\varepsilon_{t}^{Z} Z$. The cost of production is $w_{t} /\left(Z_{t} \mathbf{z}\right)$, where $w_{t}$ is the real wage, measured in units of the consumption price index, $P_{t}$. In the domestic market, firms charge a fixed markup $\theta /(\theta-1)$ over production costs: $\rho_{D, t}(\mathbf{z})=\frac{p_{D, t}(\mathbf{z})}{P_{t}}=\frac{\theta}{(\theta-1)} \frac{w_{t}}{Z_{t} \mathbf{z}}$, with $\rho_{D, t}(\mathbf{z})$ being the price of the variety in real terms.

Exports There are three costs to exporting. First, every exporter incurs a per-period fixed cost to exporting, $f_{X, t}$, as in Melitz (2003). ${ }^{19}$ Because of these fixed-costs, only the most productive (high z) firms export. Exporters incur two additional ad-valorum costs: iceberg trade costs, $\tau \geqslant 1$, and tariffs charged by Foreign at the dock (FOB basis), $\mathrm{Y}_{t}$. Export prices, $\rho_{X, t}(\mathbf{z})$, include both of these costs: $\rho_{X, t}(\mathbf{z})=\frac{p_{X, t}(\mathbf{z})}{P_{t}^{*}}=\mathbb{Q}_{t}^{-1}\left(1+Y_{t}\right) \tau \rho_{D, t}(\mathbf{z})$. Note that export prices are expressed in units of the destination country price index; here, exports from the foreign country into the home country are expressed in the home price index.

Dividends from domestic, $d_{D, t}(\mathbf{z})$, and foreign sales $d_{X, t}(\mathbf{z})$ are therefore expressed as:

$$
\begin{aligned}
& d_{D, t}(\mathbf{z})=\frac{1}{\theta}\left[\rho_{D, t}(\mathbf{z})\right]^{1-\theta} C_{t} \\
& d_{X, t}(\mathbf{z})=\frac{Q_{t}}{\theta}\left[\rho_{X, t}(\mathbf{z})\right]^{1-\theta} C_{t}^{*}-f_{X, t}, \text { if firm } \mathbf{z} \text { exports, } 0 \text { otherwise. }
\end{aligned}
$$

The firm's total dividends, $d_{t}(\mathbf{z})$, are equal to the sum of both domestic and foreign dividends: $d_{t}(\mathbf{z})=d_{D, t}(\mathbf{z})+d_{X, t}(\mathbf{z})$.

\footnotetext{
${ }^{19}$ These costs are measured in units of effective labor: $f_{X, t}=f_{X} \frac{w_{t}}{Z_{t}}$.
} 
Firm Averages We can define a cutoff level, $\mathbf{z}_{X}$, such that firms will export if firm productivity $\mathbf{z}$ is above $\mathbf{z}_{X, t}=\inf \left\{\mathbf{z}: d_{X, t}(\mathbf{z})>\mathbf{0}\right\}$ from the distribution $G(\mathbf{z})$. Therefore, we can denote the exporters among the mass of producing firm, as $N_{X, t}=\left[1-G\left(\mathbf{z}_{X, t}\right)\right]$. The average productivity for all producing firms, $\tilde{\mathbf{z}}_{D}$, and for exporters, $\tilde{\mathbf{z}}_{X, t}$, can then be written as:

$$
\begin{aligned}
\tilde{\mathbf{z}}_{D} & \equiv\left[\int_{\mathbf{z}_{\min }}^{\infty} \mathbf{z}^{\theta-1} d G(\mathbf{z})\right]^{1 /(\theta-1)}, \\
\tilde{\mathbf{z}}_{X, t} & \equiv\left[\frac{1}{1-G\left(\mathbf{z}_{X, t}\right)} \int_{\mathbf{z}_{X, t}}^{\infty} \mathbf{z}^{\theta-1} d G(\mathbf{z})\right]^{1 /(\theta-1)},
\end{aligned}
$$

respectively.

As shown in Melitz (2003), these firm averages summarize all the relevant information for aggregate variables. In particular, $\tilde{p}_{D, t} \equiv p_{D, t}\left(\tilde{\mathbf{z}}_{D}\right)$ represents the average nominal domestic price for home firms, and $\tilde{p}_{X, t} \equiv p_{X, t}\left(\tilde{\mathbf{z}}_{X, t}\right)$, the nominal price of home exports to Foreign. The home price index can thus be redefined as: $P_{t}=\left[N_{D, t}\left(\tilde{p}_{D, t}\right)^{1-\theta}+N_{X, t}^{*}\left(\tilde{p}_{X, t}^{*}\right)^{1-\theta}\right]^{1 /(\theta-1)}$, where $N_{X, t}^{*}$ denotes foreign firms that export to Home, and $\tilde{p}_{X, t}^{*}$ denotes their corresponding nominal average price. Alternatively this can be expressed in real terms as: $1 \equiv N_{D, t}\left(\tilde{\rho}_{D, t}\right)^{1-\theta}+$ $N_{X, t}^{*}\left(\tilde{\rho}_{X, t}^{*}\right)^{1-\theta}$. Average dividends from the domestic sales of all home producers can be expressed as $\tilde{d}_{D, t} \equiv d_{D, t}\left(\tilde{\mathbf{z}}_{D}\right)$, while average dividends from foreign sales of all home exporters can be denoted by $\tilde{d}_{X, t} \equiv d_{X, t}\left(\tilde{\mathbf{z}}_{X, t}\right)$. Total average dividends from home producers is equal to the sum of dividends earned domestically and from exporting: $\tilde{d}_{t} \equiv \tilde{d}_{D, t}+\left[1-G\left(\mathbf{z}_{X, t}\right)\right] \tilde{d}_{X, t}$.

\subsection{Foreign}

In what follows we describe the foreign economy. To simplify the exposition, we abstract from describing the characteristics of the foreign economy that that are identical to those in the home country. These details have been relegated to the appendix, where we also show the equilibrium conditions for the full model. 


\subsubsection{Consumption Bundles}

Households have access to two different types of consumption goods: licensed products and products made using appropriated technology capital, which we will call "appropriated" as a short-hand. Foreign licensed firms are heterogeneous and pay licensing fees to start operating, just as home firms do. As a result, these firms have access to international markets and their goods may be freely traded across borders.

The consumption bundle of licensed goods for Foreign mimics the bundle of aggregate consumption in the home country: $C_{t}^{*}=\left(\int_{\omega \in \Omega_{t}^{*}} C_{t}^{*}(\omega)^{(\theta-1) / \theta} d \omega\right)^{\theta /(\theta-1)}{ }^{20}$ The price of the foreign composite of licensed goods is: $P_{t}^{*}=\left(\int_{\omega \in \Omega_{t}^{*}} p_{t}^{*}(\omega)^{1-\theta} d \omega\right)^{1 /(\theta-1)} \cdot{ }^{21}$ Notice, however, that the subset of goods available for consumption in the foreign economy may differ from the one available in the home economy $\left(\Omega_{t}^{*} \neq \Omega_{t}\right)$.

The output of the appropriating sector in Foreign, $Y_{\mathbf{c}, t}^{*}$ can only be consumed within its national boundaries: $C_{c, t}^{*}=Y_{\mathbf{c}, t}^{*}$. In Foreign, aggregate consumption, $C_{\mathbf{a}, t}^{*}$, is the sum of licensed, $C_{t}^{*}$, and of appropriated, $C_{\mathbf{c}, t}^{*}$ goods: $C_{\mathbf{a}, t}=C_{t}^{*}+C_{\mathbf{c}, t}^{*}$. For simplicity, we assume that appropriators replicate all the goods (imported and domestically produced) in the licensed basket chosen by the foreign households. As in Holmes et al (2015), we further assume that appropriators are markedly less efficient at producing these goods than licensed producers are (details below). Under the assumption of perfect substitution, reduced production efficiency is isomorphic to the case where appropriators are as efficient as licensed producers but consumers heavily discount the goods they produce. ${ }^{22}$ One can think of goods made with appropriated technology capital as being counterfeit goods and, therefore, consumers may prefer the licensed good. Perfect substitution between counterfeit and licensed goods implies that the price of the latter, $P_{t}^{*}$, also serves as the aggregate consumer-price index. As in the case of Home, this price will serve as the numeraire in Foreign and, therefore, variables will be expressed in real terms.

\footnotetext{
${ }^{20}$ Recall that we have assumed that all consumption at home is licensed due to full enforcement of intellectual property rights.

${ }^{21}$ The resulting demand for each individual good $\omega$ is $c_{t}^{*}(\omega)=\left(\rho_{t}^{*}(\omega)\right)^{-\theta} C_{t}^{*}$, where prices of the individual varieties are expressed in units of the foreign currency.

${ }^{22}$ For instance, the scenario in which 1.2 units of a fake good delivers the same utility than 1 unit of (an otherwise identical) licensed good is equivalent to the scenario in which appropriators are 20 percent less productive than licensed ones, while consumers that values these goods equally.
} 


\subsubsection{Households in the Foreign Country}

Every period, representative foreign households inelastically supply a labor to licensed, $L_{t}^{*}$, and appropriating, $L_{\mathbf{c}, t}^{*}$, firms, which we normalize to one $\left(L_{t}^{*} \equiv L_{\mathbf{c}, t}^{*} \equiv L^{*} \equiv 1\right)$. Labor is assumed to be immobile across sectors in order to simplify the analysis. They maximize intertemporal utility in a similar fashion to their home counterparts: $\mathbb{E}_{s=t}^{\infty} \sum^{s-t} C_{h^{*}, s}^{1-\gamma} /(1-\gamma)$. Furthermore, foreign households own both the licensed and appropriating firms; they hold shares in a diversified mutual fund of publicly traded licensed firms and directly own appropriating firms. Share holdings of the mutual funds are adjusted to account for entry and exit of licensed firms in Foreign in the same way as was described for Home. Appropriating firms are homogeneous and operate a Cobb-Douglas technology in order to produce. One important feature of the model is that foreign households have joint ownership of licensed and appropriating firms. ${ }^{23}$ This implies that when foreign households pay royalties to home entrepreneurs, they internalize the fact that their own appropriating firms will seize part of the technology capital transferred from home entrepreneurs.

Foreign households' budget constraint may be expressed as:

$$
\tilde{v}_{t}^{*} N_{E, t}^{*}+C_{\mathbf{a}, t}^{*}=w_{t}^{*} L^{*}+w_{\mathbf{c}, t}^{*} L_{\mathbf{c}}^{*}+R_{\mathbf{c}, t}^{*} M_{\mathbf{c}, t-1}^{*}+N_{D, t}^{*} \tilde{d}_{t}^{*}+\Pi_{t}^{*}
$$

where $w_{t}^{*}$ and $w_{\mathbf{c}, t}^{*}$ are the wages paid by licensed and appropriating producers, respectively, $M_{\mathbf{c}, t-1}^{*}$ is the stock of appropriated technology the appropriating firms possesses and $R_{\mathbf{c}, t}^{*}$ is its implicit rental rate. The rest of the variables in Equation (18) are the foreign equivalents to variables already described for the home economy.

\subsubsection{Firms in the Foreign Country}

Licensed firms in the foreign country solve a problem that is identical to that solved by their counterparts in the home country. The resulting optimality conditions are identical to those

\footnotetext{
${ }^{23}$ The data supports this feature. Appropriators have begun to manufacture their goods in the same factory that produces authentic goods. Yuandan goods is a term used to describe counterfeit goods that are made in the same factory as legitimate designer pieces without authorized permission to do so. These goods produced illegally using scraps and leftover materials from the genuine products and then sold on the black market.
} 
described in Section 3.1.4. Appropriating firms perform two set of distinctive set of activities. They appropriate the home entrepreneurs' technology for their own use and then they combine it with labor to produce output.

Appropriated Technology Capital The law of motion for appropriated technology capital is as follows:

$$
M_{\mathbf{c}, t}^{*}=\left(1-\delta_{M}^{*}\right) M_{\mathbf{c}, t-1}^{*}+h\left(q_{t}\right) M_{t-1}^{*},
$$

where $M_{t-1}^{*}$ is technology capital transferred by home entrepreneurs to licensed firms in Foreign, and $h\left(q_{t}\right) M_{t-1}^{*}$ is the technology capital that is appropriated. $M_{\mathbf{c}, t}^{*}$ is the resulting stock of appropriated technology capital, and $\delta_{M}^{*} \geq \delta_{M}$, is its depreciation rate. ${ }^{24}$

Production Appropriators combine labor $L_{\mathbf{c}}^{*} \equiv 1$ with the appropriated technology capital in order to produce output using a Cobb-Douglas technology: $Y_{\mathbf{c}, t}^{*}=Z_{t}^{*} \tilde{\mathbf{z}}_{D}^{*} \Psi^{*}\left(M_{\mathbf{c}, t-1}^{*}\right)^{\alpha}$, where $\alpha$ is the technology capital share and $\Psi^{*}<1$ is the loss in productivity that results from appropriation. Labor productivity is defined by two factors, $Z_{t}^{*} \tilde{\mathbf{z}}_{D}^{*}$. The first of these, $Z_{t}^{*}=\varepsilon_{t}^{Z^{*}} Z^{*}$ is TFP - where $\varepsilon_{t}^{Z^{*}}$ accounts for an exogenous productivity innovation to all firms in Foreign. The second, $\tilde{\mathbf{z}}_{D}^{*}$ is time invariant and represents the average productivity of licensed producers: $G\left(\mathbf{z}^{*}\right)$ with support $\left[\mathbf{z}_{\min }^{*}, \infty\right)$. Firm maximization pins down the implicit rental rate for the appropriated technology, $R_{\mathbf{c}, t}^{*}$, and the wages in the appropriating sector: $R_{\mathbf{c}, t}^{*}=\alpha Y_{\mathbf{c}, t}^{*} / M_{\mathbf{c}, t-1^{\prime}}^{*}$ $w_{\mathbf{c}, t}^{*}=(1-\alpha) Y_{\mathbf{c}, t}^{*}$.

\subsection{Policy choices and Additional Variables}

Tariff policy We incorporate two policy levers into the model. We are interested in the interplay between international trade and the diffusion of technology, so we incorporate parameters which govern tariffs and the enforcement of intellectual property. It is important to note that

\footnotetext{
${ }^{24}$ Consistent with the evidence, appropriated technology is allowed to depreciate at a faster rate. For instance, if appropriators encounter a problem they cannot rely on the technical support provided by the original developers. Due to lack of data availability, in the model parameterization we assume that $\delta_{M}^{*}=\delta_{M}$.
} 
there is no policy choice; rather, we will be analyzing exogenous shocks to these policies. However, we will allow for shocks to one policy to impact the other.

Home tariffs levied on foreign imports, $\mathrm{Y}_{t}^{*}$, are defined as $\mathrm{Y}_{t}^{*}=\varepsilon_{t}^{\mathrm{Y}^{*}}\left(\varepsilon_{t}^{q}\right)^{\phi} \mathrm{Y}^{*}$, where $\varepsilon_{t}^{\mathrm{Y}^{*}}$ captures exogenous innovations to these tariffs. Note that $\varepsilon_{t}^{q}$ denotes an exogenous innovation to the enforcement of intellectual property rights in Foreign. Therefore, when $\phi>0$, a change in IPR enforcement will impact the home country's level of tariffs. In this sense, we are allowing for the possibility of the home economy retaliating with lower (higher) tariffs if its foreign counterpart strengthens (relaxes) its protection and enforcement of intellectual property rights, $\varepsilon_{t}^{q}$. Since there is no appropriation of intellectual capital in Home, foreign tariffs levied on home exports, $Y_{t}$, are completely exogenous by definition: $Y_{t}=\varepsilon_{t}^{Y} Y$.

If we re-examine Equation (3)

$$
h\left(q_{t}\right)=\Theta_{t}\left[q_{t} \exp \left(-\eta\left(1-q_{t}\right)\right)\right] ; \text { with } \eta_{t}>0,
$$

and define $\Theta_{t}=\varepsilon_{t}^{q}\left(\varepsilon_{t}^{Y^{*}}\right)^{\phi^{*}}$ where, again, $\varepsilon_{t}^{q}$ represents Foreign's intellectual property rights enforcement regime and $\varepsilon_{t}^{Y^{*}}$ represents exogenous innovations to tariffs imposed by Home on imports from Foreign. We can see that if $\phi^{*}>0$ then an innovation to tariffs levied on foreign goods by Home will result in more appropriation. Therefore, we will also allow Foreign to relax (strengthen) its protection of IPR in response to higher (lower) tariffs imposed by Home.

Additional Variables There is no financial integration across countries. Lack of international lending and borrowing implies that the following balanced-trade condition must hold:

$$
\frac{1}{\left(1+Y_{t}\right)} \mathbb{Q}_{t} N_{X, t}\left(\tilde{\rho}_{X, t}\right)^{1-\theta} C_{t}^{*}=\frac{1}{\left(1+Y_{t}^{*}\right)} N_{X, t}^{*}\left(\tilde{\rho}_{X, t}^{*}\right)^{1-\theta}\left(C_{h, t}+C_{e, t}\right) .
$$

Specifically, the value of home exports must equal the value of foreign exports, with only licensed goods being traded internationally. Output is computed with the income-based approach and is equal to the following in the home country:

$$
y_{t}=w_{t} L+N_{D, t} \tilde{d}_{D, t}+R_{t} M_{t-1} N_{E, t}+\mathbb{Q}_{t} q_{t} R_{t}^{*} M_{t-1}^{*} N_{E, t}^{*} .
$$


The equation differs slightly for Foreign, as income sources differ across the two countries. Foreign output can be written as

$$
y_{t}^{*}=w_{t}^{*} L^{*}+w_{\mathbf{c}, t}^{*} L_{\mathbf{c}}^{*}+N_{D, t}^{*} \tilde{d}_{t}^{*}+R_{\mathbf{c}, t}^{*} M_{\mathbf{c}, t-1}^{*} .
$$

All tariff revenues are rebated in a lump-sum manner to the households in both countries: $\Pi_{h, t}=\left(\mathrm{Y}_{t}^{*} /\left(1+\mathrm{Y}_{t}^{*}\right)\right) N_{X, t}^{*}\left(\tilde{\rho}_{X, t}^{*}\right)^{1-\theta} C_{h, t}, \Pi_{t}^{*}=\left(\mathrm{Y}_{t} /\left(1+\mathrm{Y}_{t}\right)\right) N_{X, t}\left(\tilde{\rho}_{X, t}\right)^{1-\theta} C_{t}^{*}$, as well as to entrepreneurs in the home country: $\Pi_{e, t}=\left(\mathrm{Y}_{t}^{*} /\left(1+\mathrm{Y}_{t}^{*}\right)\right) N_{X, t}^{*}\left(\tilde{\rho}_{X, t}^{*}\right)^{1-\theta} C_{e, t}$.

In what follows, we will assess the welfare implications of different policy regimes. We measure welfare for each agent in the economy as the discounted utility from the stream of con-

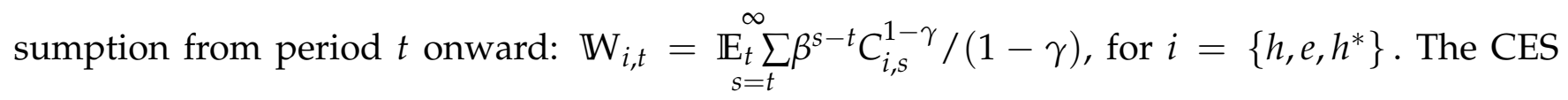
consumption preferences specification implies that price indexes can be decomposed into average prices and product variety: $P_{t}=\tilde{P}_{t}\left(N_{D, t}+N_{X, t}^{*}\right)^{1 /(1-\theta)}$, where $\tilde{P}_{t}$ is the average nominal price of all the varieties sold in Home, and $\left(N_{D, t}+N_{X, t}^{*}\right)^{1 /(1-\theta)}$ captures the variety of products. An analogous expression for holds for Foreign. $\tilde{P}_{t}$ is closer to the empirical measures used by statistical agencies. Therefore, a theoretical counterpart to the empirical exchange rate can be defined as $\tilde{\mathbb{Q}}_{t}=\varepsilon_{t} \tilde{P}_{t}^{*} / \tilde{P}_{t}$. For practical purposes, we will focus on this variable in the model simulations.

\section{Model Parameterization}

The distribution of firm productivity draws is Pareto with lower bound $\mathbf{z}_{\min }$ and shape parameter $k>\theta-1: G(\mathbf{z})=1-\left(\mathbf{z}_{\min } / \mathbf{z}\right)^{k}$, where $k$ characterizes the dispersion of the draws. Average productivities $\tilde{\mathbf{z}}_{D}$ and $\tilde{\mathbf{z}}_{X, t}$ are defined as $\tilde{\mathbf{z}}_{D}=v \mathbf{z}_{\min }$ and $\tilde{\mathbf{z}}_{X, t}=v \mathbf{z}_{X, t}$, where $v \equiv$ $\{k /[k-(\theta-1)]\}^{1 /(\theta-1)}$. The foreign economy has an identical distribution. As in Ghironi and Melitz (2005), we pick $\theta=2.3$ which is the same value in Bernard et al (2003). In this last paper, the estimates for the standard deviation of the log of U.S. plant sales is 1.67. In the model, this standard deviation is $1 /(k-\theta-1)$, which implies that $k=3.4$. We assume that Foreign is less productive (i.e. less developed). Without loss of generality, $\mathbf{z}_{\min }$ is normalized to 1 and $\mathbf{z}_{\min }^{*}$ is 
set to 0.2 . This implies that in the initial stationary equilibrium, the per capita output ratio for Home and Foreign is 3.09. This coincides with the current per capita output ratio for U.S. and China, measured in purchasing power parity terms. Tariffs imposed on Home, $\mathrm{Y}_{t}$, and foreign exports, $\mathrm{Y}_{t}^{*}$ are $5.9 \%$ and $2.9 \%$, respectively. This coincides with the mean effective bilateral tariffs that China and the U.S. impose on one another for the period (2002-2017). We choose this sample period to include only the years after China's most favoured nation status became permanent (December 2001). The size of the firm exit shock $(\delta=0.025)$ matches the annual $10 \%$ job destruction observed in the U.S. data.

Each period is one quarter. Therefore, we set $\beta=0.99$ and $\gamma=2$,which are the standard values in the literature. The iceberg transportation $\operatorname{cost}, \tau$, is set to 1.68 and is chosen to match the bilateral U.S./China trade cost estimates from ESCAP-World Bank Trade Cost Database for 2010. We normalize $f_{e}$ to 1 and set the ratio of the fixed cost of entry to the fixed cost of exporting, $f_{e} / f_{X}$, to match the steady-state share of expenditure of domestic goods in Ghironi and Melitz (2005). This share is 0.73 and in the model implies that exporters are about $83.3 \%$ more productive than non-exporters. In the baseline calibration, we set the elasticity of retaliation in response to intellectual property (trade) policy innovations, $\phi\left(\phi^{*}\right)$, to zero, while allowing them to vary in the policy experiments discussed below.

The remaining four parameters match the estimates in Holmes et al (2015). The quarterly depreciation rate for the stock of technology capital, $\delta_{M}$, is 0.20 , while its associated income share, $\alpha$, is 0.07 . The productivity loss that occurs when technology capital is appropriated, $\Psi^{*}$, is set to 0.9 , which implies that wages in the licensed sector are $78.9 \%$ higher that in the appropriating one. Finally, the parameter that pins down the convexity of the technology transfer is set to $\eta=10$.

Unless explicitly stated parameter values for Home and Foreign are symmetric. This symmetry reflects limitations of firm-level data for the Chinese economy. At the same time, this approach eases the comparison in the cross-country transitional dynamics described below. 


\section{Model Dynamics}

We now examine the model response to several different policy regime and economic shocks.

\subsection{An Increase in Tariffs on Foreign Goods}

We begin by assuming that the interaction between shocks to the enforcement of intellectual property rights and shocks to tariffs levied on foreign goods at Home is zero $\left(\phi, \phi^{*}=0\right)$. Here, we wish to explore the impact of an exogenous increase in tariffs on imports to Home from Foreign when there is no scope for retaliation in foreign policy. We impose a modest unilateral exogenous $1 \%$ increase in tariffs applied by Home on goods imported from Foreign, increasing the tariff rate from $2.9 \%$ to $3.9 \%$. Transitional dynamics are depicted in Figure 1 as percentage deviations from the original stationary equilibrium.

As standard trade theory would predict, tariffs induce a significant decrease in imports, and given the balanced trade assumption, an equivalent decrease in exports. As a result, the number of exporting firms decreases and consumers in both countries consume a bundle of goods with an increased proportion of domestic varieties. This substitution away from imports results in more investment in the creation of domestic varieties, which manifests as an increase in domestic firm entry. Furthermore, the increase in tariffs targeting foreign goods and the resulting decrease in the demand for these products lowers their equilibrium price level, as well as foreign wages. Cheaper foreign goods translates into a slight real exchange appreciation (depreciation) for Home (Foreign) (i.e. $\tilde{\mathbb{Q}}_{t}$ decreases), which, in turn, means that the foreign country has a competitive edge, ${ }^{25}$ thereby inducing relatively more firm creation in the foreign economy than in the home economy.

All else equal, the increase in firm entry in both countries implies more total royalty receipts for the home entrepreneurs that supply the necessary technology capital for firm creation. ${ }^{26}$ Notice, however, that the investment in new technology capital declines slightly. Even though there is now more firm entry, meaning that $N_{E, t}$ increases, the rental rate for technology capital, $R_{t}$,

\footnotetext{
${ }^{25}$ Real exchange rate appreciations following an increase in tariffs is noted in the literature, e.g. Farhi et al (2014).

${ }^{26}$ Total royalty receipts from Home equal $N_{E, t} R_{t} M_{t-1}$ while royalty receipts from Foreign equal $N_{E, t}^{*} R_{t}^{*} q_{t} M_{t-1}^{*}$. Royalties are expressed in the currency of the country from which they originate.
} 
is significantly lower in the new stationary equilibrium. This is because increased tariffs lead to a decline in profits for exporting firms, which are the most productive firms in both countries. A decline in profitability for the most productive firms necessarily implies decreased expected profits for prospective new firms, lowering the expected benefit of entry thereby generating lower rental rates for technology capital. This decrease in the rental rate, in turn, reduces investment in new technology. Perhaps somewhat counter-intuitively, entrepreneurs optimally choose to increase their transfer rate $\left(q_{t}\right)$ to the foreign economy where firm entry is relative more robust. This is an attempt to increase the overall returns to their stock of technology capital. Because of this, and perhaps surprisingly, over time increased tariffs lead to an increase in the stock of appropriated technology overseas.

The output (income) impact of the increase in tariffs is negative for both countries, as it lowers the number of varieties available for consumers and forces a reallocation of production towards less productive firms. Not surprisingly, the decline in income is more pervasive in Foreign, where tariffs directly impact the profitability of the most productive firms (exporters) and, as a result, the equilibrium wages. In Home, the decline in output and aggregate income is more moderate. Two things explain this. First, total royalty payments received by entrepreneurs increase as a result of more firm entry in both countries, as consumers in each country substitute more towards the consumption of domestic goods. Second, higher tariffs result in increased lump-sum transfers to home households and entrepreneurs. Relatively more of these financial resources are channeled to domestic demand-given the costly trade assumption in this Melitz framework-ultimately benefiting home firms relatively more. In sum, the transfers partially offset the loss of competitiveness arising from the real exchange rate appreciation in Home.

Most relevant for this discussion are the welfare effects of this policy move-measured as discounted utility flows. In Foreign, the sizable decrease in household income and consumption is partly the by-product of tariffs levied on their licensed firms. In Home, these tariffs are more than enough to compensate for the decline in aggregate income. Indeed, an increase in tariffs is welfare improving for Home as it leads to a slight increase in consumption and welfare for both its households and entrepreneurs.

Tariffs are usually subject to a political and administrative delays (See for instance, Barattieri 
et al 2018). To explore how outcomes differ if there is a delay in implementation after announcement, we also conduct an experiment in which the 1\% increase in tariffs is announced 10 quarters before it is implemented. The dotted blue line in Figure 1 depicts this scenario. ${ }^{27}$ The outcome is similar to what happens above, when the tariff is implemented immediately. However, in this case home and foreign households react to the news by smoothing their consumption path. Foreign households immediately reduce their consumption to invest more in firm creation. In turn entrepreneurs, expecting higher future income, immediately increase consumption and reduce their investment in technology capital. These together explain why entrepreneurs increase the transfer rate for technology capital immediately in response to the announcement.

Tit-for-tat Trade War Now, we turn to a situation in which there is a tit-for-tat interaction which results in a trade war. Our purpose here is two-fold. First, we would like to explore what happens if Home is also subject to new tariffs, or a bilateral increase in tariffs. Second, we would like to analyze the impact of a much larger increase in tariffs. Therefore, in this experiment, we shock the model economy with a series of alternating 1\% increases in tariffs in Home and in Foreign, ending in a final increase in gross tariffs of $10 \%$ for both countries. Figure 2 depicts this Tit-for-tat escalation. Note that there is no uncertainty in our deterministic framework: all agents have perfect foresight. ${ }^{28}$ We have included the $1 \%$ unilateral increase case, our baseline experiment, in Figure 2 as the solid blue line, with the tit-for-tat trade war as the dotted brown line. We include the baseline for the purpose of comparison.

In the first panel of Figure 2, the evolution of gross tariffs $\left(1+\mathrm{Y}_{t}\right.$, depicted in red and $1+\mathrm{Y}_{t}^{*}$, in blue) depicts this escalation of the trade war. The remaining panels illustrate the model's transitional dynamics in response to these policy shocks. In our initial parameterization, the equilibrium the tariffs are significantly higher in Foreign (5.9\%) than in Home (2.9\%).

The trade war scenario highlights one important result. Even though the foreign exchange rate appreciates - as its tariff base is higher - consumption in that country declines significantly

\footnotetext{
${ }^{27}$ By assumption, there is no uncertainty about whether this tariff will actually be imposed after the announcement.

${ }^{28}$ It would be interesting to consider a possibility of uncertainty over future tariff increases; however, our current framework is not set up to analyze policy uncertainty.
} 
in this pervasive conflict. By slashing imports from Home on a massive scale, foreign consumers face substantially reduced access to consumption goods from a trade partner which is five times more productive and are forced to substitute them for goods from local producers which are much less productive. ${ }^{29}$ Meanwhile, in the home country, the effects of a drop in imports can be partially offset by the steady entry of relative more productive domestic firms over time.

In combination with our baseline results, the results from this scenario indicate that an increase in tariffs by Home begets a beggar-thy-neighbor scenario, improving its welfare at the cost of Foreign's well-being. If Foreign follows suit, by retaliating and escalating the conflict in a tit-for-tat fashion, it only serves to decrease the welfare of its own citizens. Therefore, this retaliation strategy is not a good one for the foreign country to consider; we, therefore, allow for other forms of retaliation in what follows.

\subsection{Retaliation}

In Figure 3, we again include the baseline depicting a 1\% unilateral increase in home tariffs on foreign imports, as the solid blue line. We now deviate from that baseline by allowing Foreign to respond to an exogenous increase in tariffs by increasing the appropriation of intellectual property. Recall Equation (3):

$$
h\left(q_{t}\right)=\Theta_{t}\left[q_{t} \exp \left(-\eta\left(1-q_{t}\right)\right)\right] ; \text { with } \eta_{t}>0,
$$

where $\Theta_{t}=\varepsilon_{t}^{q}\left(\varepsilon_{t}^{Y^{*}}\right)^{\phi^{*}}$. In the baseline, we set $\phi^{*}$ equal to zero, meaning that a shock to tariffs on foreign imports into the home country would not result in any change in the appropriation of home technology capital. In this experiment, instead, we set the elasticity of appropriation, $\phi^{*}$, to 5 and again shock the economy with a $1 \%$ increase in tariffs on foreign imports into Home, $\varepsilon_{t}^{Y^{*}}$. The dotted-red line illustrate the response in both economies to this scenario. Again, recall that there is no choice for the social planner in either country; the shock to tariffs is exogenous and the response in Foreign is guided by parameter choices. However, the model allows for an endogenous change in the level of appropriation in response to the tariff shock.

\footnotetext{
${ }^{29}$ Recall that in the parameterization, $\mathbf{z}_{\min }$ is normalized to 1 and $\mathbf{z}_{\min }^{*}$ is set to 0.2 .
} 
Entrepreneurs react to the change in the enforcement of intellectual property by sharply reducing the transfer of technology capital, $q_{t}$. Nevertheless, the fall in the transfer rate is not completely offset by the increase in appropriation and, therefore, there is a sizable increase in the stock of appropriated technology capital. A robust non-tradable appropriated sector displaces licensed producers in Foreign as the stock of appropriated technology capital increases. Furthermore, firm entry at Home declines substantially in response to foreign consumers substituting toward the appropriating sector and away from imported goods from Home. Therefore, the expected profitability of firm entry at Home declines and, with it, home firm creation. ${ }^{30}$

The most notable result from this experiment it that the foreign planner can fully revert the losses arising from the original imposition of tariffs by its Home counterpart, turning them into substantial consumption gains for their own households by responding to tariffs with increased appropriation. Moreover, by taking this action, the foreign country converts the slight consumption gains for home entrepreneurs in the baseline scenario to sizable losses, as royalties drop significantly when appropriation rises. Gains for the home households that were originally obtained from higher tariffs also fall with this retaliation, as home exporters now lose market share to the appropriators. To better see this, the last panel of Figure 3 aggregates the consumption of home households and entrepreneurs, showing an absolute decline following the retaliation. In summary, the imposition of tariffs increases home consumption at the expense of the foreign consumer. However, this foreign retaliation in the form of increased appropriation fully reverses the original gains for the home economy. In other words, the beggar-thy-neighbor intent of Home becomes a beggar-thyself in the face of this retaliation.

Home Tariff Retaliation in Response to Technology Capital Appropriation Figure 4 considers the case where Home retaliates to an increase in appropriation with an increase in tariffs. We think this is an interesting given the recent increase in U.S. tariffs against China which are meant, in part, to punish perceived appropriation of U.S. intellectual property by Chinese firms. We consider first an exogenous increase in the appropriation of technology capital by Foreign,

\footnotetext{
${ }^{30}$ Entry in the foreign economy only recovers in the long run, when the growth of the appropriating sector results in a notable increase in income in Foreign. Therefore, total demand for consumption increases and with it, the demand for goods produced in the licensed sector. This also explains why eventually the stock of intellectual capital slightly increases.
} 
and subsequently, a retaliation by Home in the form of an increase in tariffs. Mechanically, this means that we shock the model economy by doubling $\varepsilon_{t}^{q}$ (increasing $\varepsilon_{t}^{q}$ by $100 \%$ ) in Equation (3), which will translate into a reduction in the rate of technology transfer of roughly $10 \%$.

Recall that the tariffs imposed by Home on imports from Foreign are defined by $Y_{t}^{*}=$ $\varepsilon_{t}^{Y^{*}}\left(\varepsilon_{t}^{q}\right)^{\phi} Y^{*}$. In this experiment, we set $\phi$ equal to 1 , so that the level of these tariffs may endogenously respond to a change in appropriation. ${ }^{31}$ Here, the solid red line in Figure 4 illustrates the case where the appropriation parameter is shocked and there is no response in home policy $(\phi=0)$; the dotted blue line, instead, illustrates the model dynamics in response to the scenario with Home retaliation to this appropriation shock.

The intuition for the transitional dynamics arising from an exogenous increase in appropriation of technology capital with no retaliation is similar to the intuition described in the scenario where appropriation is increased in retaliation to increased tariffs. In this scenario, we see that there is a reduction in the rate of technology transfer and an increase in appropriated technology capital. The home country is worse off after the unilateral appropriation of technology by Foreign: entrepreneurs receive fewer royalties, as licensed producers in both countries are displaced by foreign appropriators. Households are worse off too, as foreign consumers substitute away from home imports and towards goods produced by the appropriators.

Nonetheless, Home can effectively retaliate against Foreign with a sizable increase in tariffs. As described with more detail in the description of the baseline scenario, this policy action decreases the profits and wages paid by licensed foreign firms, while making imports from Home relative more expensive due to the exchange rate depreciation. In turn, home households benefit from the extra income the receive from rebated tariffs and from cheaper imports, while their entrepreneurs see an increase in royalties as the decline in trade promotes export substitution and firm entry.

When the home country increases tariffs, it is made better off than in the case with no retaliation, at the cost of decreasing foreign welfare. It is not able to fully reverse the negative impact of appropriation on the entrepreneur; however, increasing tariffs are able to slightly improve welfare for entrepreneurs. This is because tariffs encourage home firm creation, as home consumers

\footnotetext{
${ }^{31}$ Again, we are not allowing for a choice of tariffs on the part of the home social planner.
} 
substitute towards domestic varieties. Therefore, entrepreneurs are able to reap benefits from increased royalty payments from a larger number of entering firms.

Once again, the general conclusions from this retaliation by Home are the same as the case in which Foreign retaliates. If Foreign increases its appropriation technology capital, it engages in a beggar-thy-neighbor policy: foreign consumption increases and aggregate consumption in the home economy falls. These results are reversed when the home planner implements a decisive tariff retaliation, rendering the initial act of appropriation as a beggar-thyself scenario.

To conclude, both countries have a trigger strategy that can punish the other if it deviates from the original stationary equilibrium. This would potentially make the original equilibrium stable and the threat of tariffs or intellectual property appropriation not credible.

\subsection{An Increase in Total Factor Productivity}

We now study the case where the country-level productivity, TFP, increases in each country. Figure 5 describes model's dynamics in response to an increase in Home (blue solid) and Foreign (red dotted) productivity. All agents benefit in either of these scenarios. Quantitatively, agents benefit significantly more when the productivity increase occurs in their own country, both in terms of output and consumption.

The presence of more productive firms incentivizes firm entry and leads to a higher rental rate for technology capital in equilibrium. Noticeably, in the standard trade model with no technology capital, an increase in productivity at Home will result in a net destruction of firms in the foreign economy (i.e. the exit rate is higher than the entry rate). That is, as more productive home firms enter, less competitive foreign firms are displaced. This is not the case in this model. As entrepreneurs accumulate more technology capital, they transfer more of it to foreign firms. Therefore, the implicit rental rate in the foreign economy drops which, in turn, incentivizes more entry despite lower relatively productivity.

If the TFP shock occurs in Foreign, the reaction of the entrepreneurs is more muted. Notably, the technology transfer rate to Foreign, $q_{t}$, barely changes after this shock. The convex form of $h($.$) implies the degree of appropriation increases exponentially with the rate of trans-$ 
fer. Ultimately, this prevents the entrepreneurs from transferring too much capital despite the productivity gains abroad. ${ }^{32}$

\section{Conclusion}

In this paper, we have provided a unified framework in which to analyze the interaction between international trade and the development and diffusion of technology capital. We have built into this framework two important policy levers - tariffs and enforcement of intellectual property - in order to analyze how retaliation in the face negative policies from a foreign counterpart impact both the home and the foreign country. To our knowledge, ours is the first paper to provide a unified framework in which to study the interplay between trade and the appropriation of intellectual property by foreign entities. We therefore provide an important bridge for policymakers who wish to study the current interactions between China and the United States. We find that the possibility of retaliation can effectively deter each country from engaging in a policy that, if unanswered, will negatively impact the other. In this sense, there is scope for cooperation between the two countries.

We have made a number of abstractions in our analysis. First, our model only includes two countries. There are a number of ways including an additional country in the model would enrich the analysis. For example, it would be interesting to consider a case where goods produced using appropriated technology could be re-sold to a third country, thus increasing the cost of appropriation to the home country. Similarly, one could imagine a scenario in which firms would have an incentive to move production to the third country in response to an increase in tariffs on goods made in one country but not on goods made in the third. ${ }^{33}$

Another limitation of our two-country set-up is that technology capital is only created in the

\footnotetext{
${ }^{32}$ The empirically-consistent hump-shaped response of the real exchange rate to technology shocks mimics the model dynamics in Ghironi and Melitz (2005). The number of producers increases in the new stationary equilibrium. This leads to an increase in the demand for inelastic labor, which ultimately leads to an appreciation of the labor costs and real exchange rate appreciation. However, in the short-run -before firm entry takes place- the increase in productivity results in excess supply of effective labor units that lowers the labor cost of production, resulting in a real exchange rate depreciation.

${ }^{33}$ There is an existing literature on tariff-jumping, but this literature does not include an analysis of technology capital and its appropriation.
} 
more developed country. While in the data it is true that the vast majority of new technologies are developed in advanced economies, a three country set-up would allow researchers to explore the interplay between two economies which develop new technologies and how the less developed country might substitute trade with a second advanced economy, for example the European Union, if the first, for example the United States, were to impose higher tariffs. This substitution of trade partners might have important implications for both the more and the less advanced countries.

Most importantly, we have not engaged in optimal policy design. We believe that this is an important and interesting avenue for future research. The framework we have built treats policies as primarily exogenous, as they are subject to exogenous shocks. Even when we allow for one policy to endogenously respond to the other, there is a policy rule that governs this response. While we believe that this is very useful for understanding the impact that these policies have upon agents in the economy, it would also be useful to expand upon our analysis to see whether these policies are mimicking what is optimal from the stand point of a social planner. We believe that a fruitful line of future research will build upon the framework presented here in order to analyze the game theoretical interactions of policy makers. 


\section{References}

Alessandria, G. and H. Choi, 2007. Do sunk costs of exporting matter for net export dynamics? Quarterly Journal of Economics 122, no. 1: 289-336.

Akcigit, U., S.T. Ates, and G. Impullitti, 2018. "Innovation and Trade Policy in a Globalized World." NBER Working Papers 24543, National Bureau of Economic Research, Inc.

Acharya, R.C. and W. Keller, 2009. "Technology Transfer through Imports." Canadian Journal of Economics 42, no. 4 (November): 1411-1448.

Barbiero, O., Farhi, E., Gopinath, G., and O. Itskhoki, 2017. "The Economics of Border Adjustment Tax." Mimeo, Harvard University and Princeton University.

Batattieri, A., Cacciatore, M., and F. Ghironi, 2018. "Protectionism and the Business Cycle." NBER Working Papers 24353, National Bureau of Economic Research, Inc.

Bilir, L.K., 2014. "Patent Laws, Product Life-cycle Lengths, and Multinational Activity." American Economic Review 104, no. 7 (July): 1979-2013.

Blonigen, B.A., Tomlin, K. and W.W. Wilson, 2004. "Tariff-jumping FDI and Domestic Firms Profits." Canadian Journal of Economics 37, no. 3 (August): 656-77.

Boler, E. A., A. Moxnes, and K.H. Ulltveit-Moe, 2012. "Technological Change, Trade in Intermediates and the Joint Impact on Productivity." CEPR Discussion Paper no. 8884.

Branstetter, L., R. Fisman, and C.F. Foley, 2006. "Do Stronger Intellectual Property Rights Increase International Technology Transfer? Empirical Evidence from U.S. Firm-Level Panel Data." Quarterly Journal of Economics 121, no 1 (February): 321-349.

Caselli, F. and W.J. Coleman, 2001. "Cross-Country Technology Diffusion: The Case of Computers." American Economic Review Papers and Proceedings 91, no. 2 (May): 328-335.

Coelli, F., A. Moxnes, and K.H. Ullveit-Moe, 2016. “Better, Faster, Stronger: Global Innovation and Trade Liberalization." CEPR Discussion Paper no. 11506.

Erceg, C., Prestipino, A., and A. Raffo, 2017. "The Macroeconomic Effects of Trade Policy." Mimeo, Board of Governors of the Federal Reserve System.

Farhi, E. Gopinath, G. and O. Itskhoki, 2014. "Fiscal Devaluations." Review of Economic Studies 81, no. 2 (April): 725-760.

Holmes, T., McGrattan, E.R. and E. Prescott, 2015. “Quid Pro Quo: Technology Capital Transfers for Market Access in China." The Review of Economic Studies 82, no. 3 (July): 11541193.

Ghironi, F. and M. Melitz, 2005. International Trade and Macroeconomic Dynamics with Het- 
erogeneous Firms. Quarterly Journal of Economics 120 (August): 865-915.

Jiang, K., Keller, W., Qiu, L.D., and W. Ridley, 2018. “International Joint Ventures and Internal vs. External Technology Transfer: Evidence from China," NBER Working Papers 24455, National Bureau of Economic Research, Inc.

Lee, J. and E. Mansfield, 1996. "Intellectual Property Protection and U.S. Foreign Direct Investment." The Review of Economics and Statistics 78, no. 2 (May): 181-186.

Linde, J., and A. Pescatori, 2017. "The Macroeconomic Effects of Trade Tariffs: Revisiting the Lerner Symmetry Result." Mimeo, International Monetary Fund.

Lin, J. and W.F. Lincoln, 2017. “Pirate's Treasure." Journal of International Economics 109: 235-245.

McGrattan, E. R. and E. Prescott, 2009. Openness, Technology Capital, and Development, Journal of Economic Theory 144, no. 6 (November): 2454-2476.

McGrattan, E. R. and E.C. Prescott, 2010. "Technology Capital and the US Current Account." American Economic Review 100, no.4 (September): 1493-1522. Melitz, M., 2003. "The Impact of Trade on Aggregate Industry Productivity and Intra-Industry Reallocation." Econometrica 71, no. 6 (November): 1695-1725.

Perla, J., Tonetti, C., and M. Waugh, 2019. “Equilibrium Technology Diffusion, Trade, and Growth." Working Paper.

Smith, P.J., 2001.“How Do Foreign Patent Rights Affect U.S. Exports, Affiliate Sales, and Licenses." Journal of International Economics 55, no. 2 (December): 411-439.

Waddle, A., 2019. "Trade, Technological Change and the Skill Premium: The Case of Mexico." Working Paper.

Xu, B. and J. Wang, 2001. "Capital Goods and R\&D Spillovers in the OECD." Canadian Journal of Economics 32, no. 5 (November): 1258-1274. 
Figure 1. Increase in Home Tariffs on Imported Foreign Goods
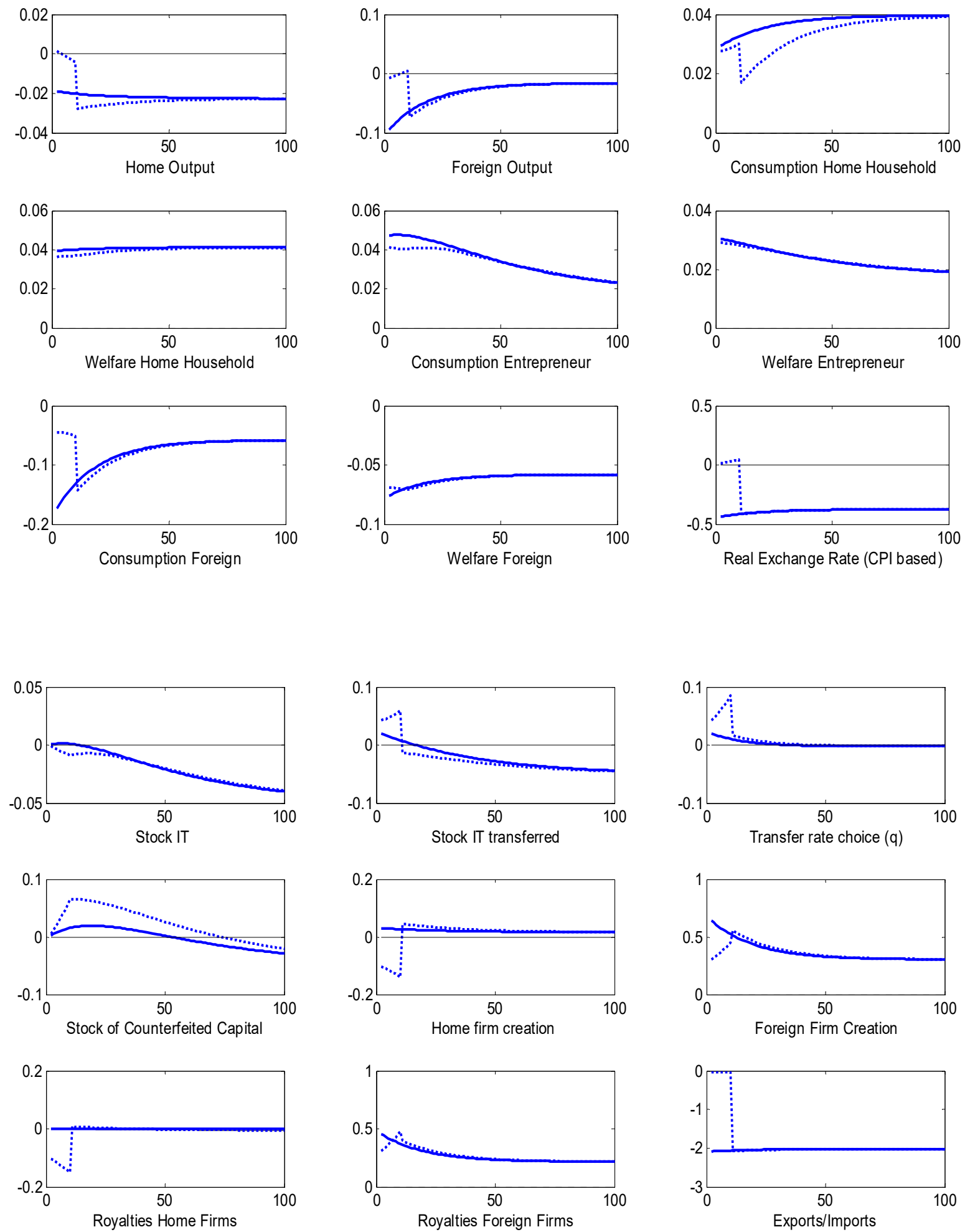

Note: The solid-blue line displays the model's response to an immediate permanent $1 \%$ increase in tariffs. The dotted line considers the same tariff increase, which in this case is applied with a delay of 10 quarters. 
Figure 2. Tit-for-Tat Trade War Scenario
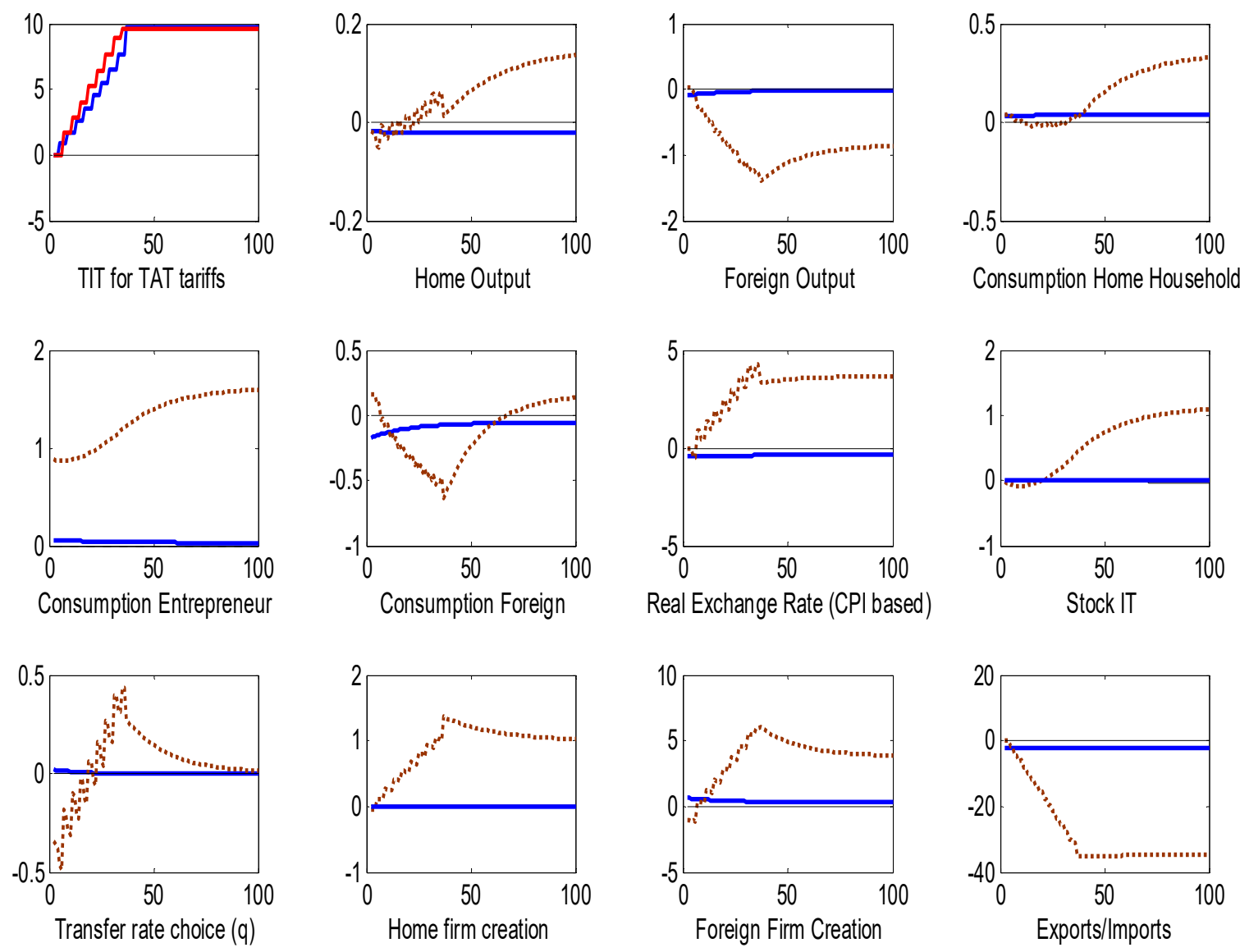

Note: The solid-blue line replicates the case displayed Fig. 1 (i.e. a 1\% percent tariff increase on imported goods from Foreign). The dotted-brown line considers a tit-for-tat tariff escalation in which each country matches the tariff imposed by the other until they converge to the level depicted in the first panel. In this first panel, blue indicates tariffs on imported goods from Foreign, and the red line the opposite. 
Figure 3. An Increase in Home Tariffs with and without Foreign retaliation.
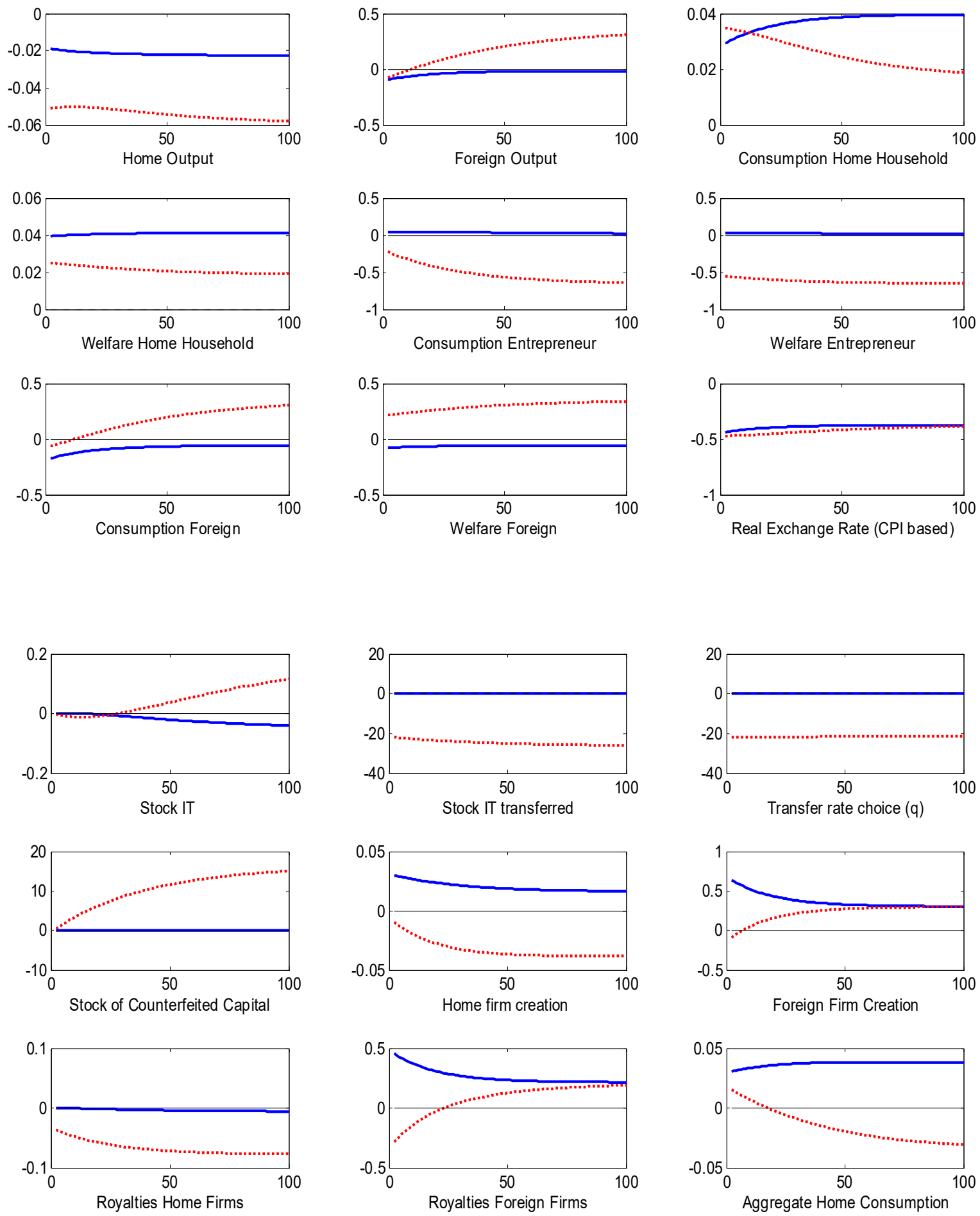

Note: The solid-blue line displays an increase of Home Tariffs on imported goods from Foreign. The dotted-red line reflects the same scenario, which in this case is retaliated by Foreign with an increase on the appropriation rate of Home's Technology Capital. 
Figure 4. An Increase in Technology Capital Appropriation with and without Home retaliation.
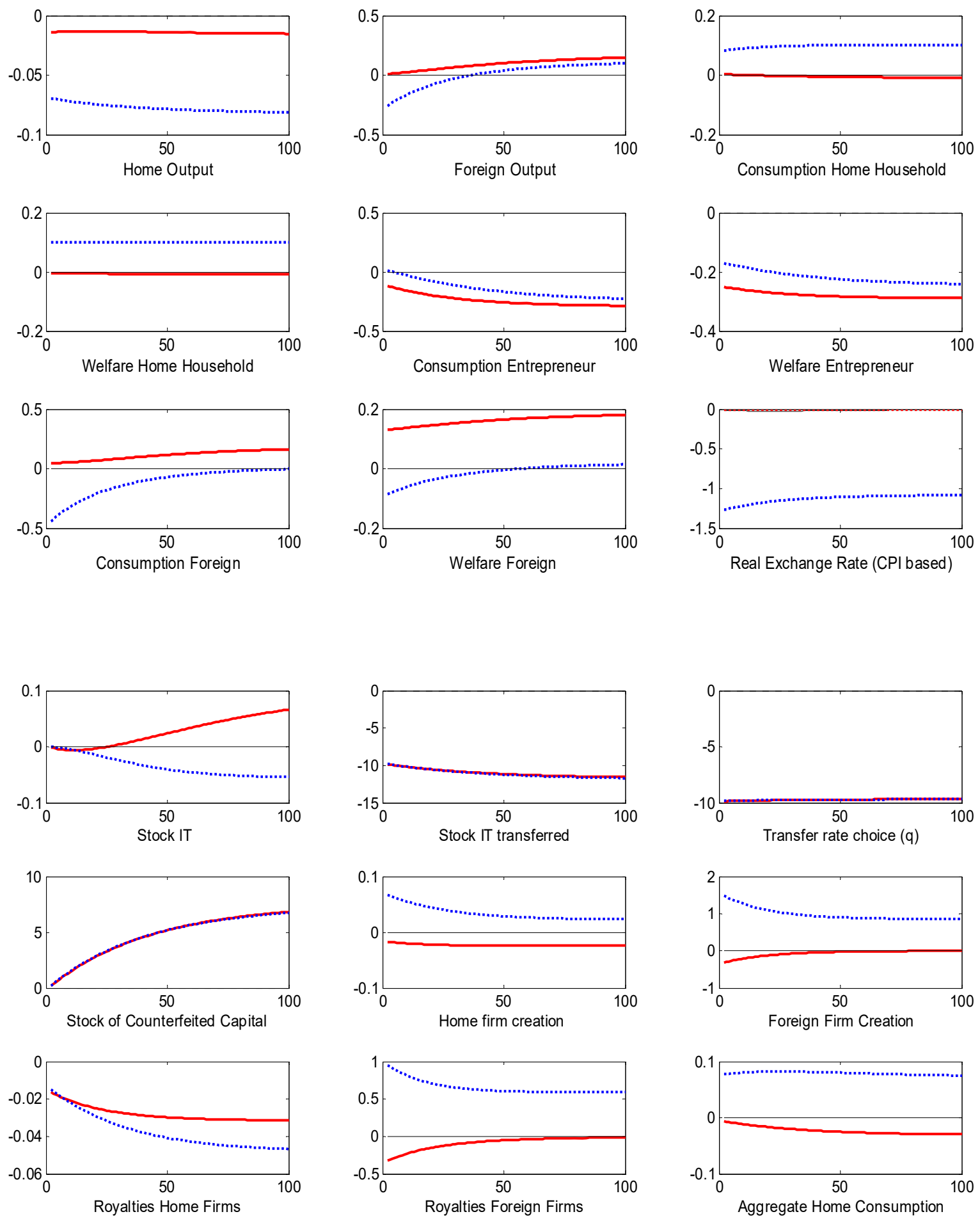

Note: The solid-red line displays an increase in foreign appropriation of Home's Technology Capital. The dottedblue line reflects the same scenario, which in this case is retaliated with an increase of Home tariffs on imported goods from Foreign. 
Figure 5. Productivity increase in Home and Foreign
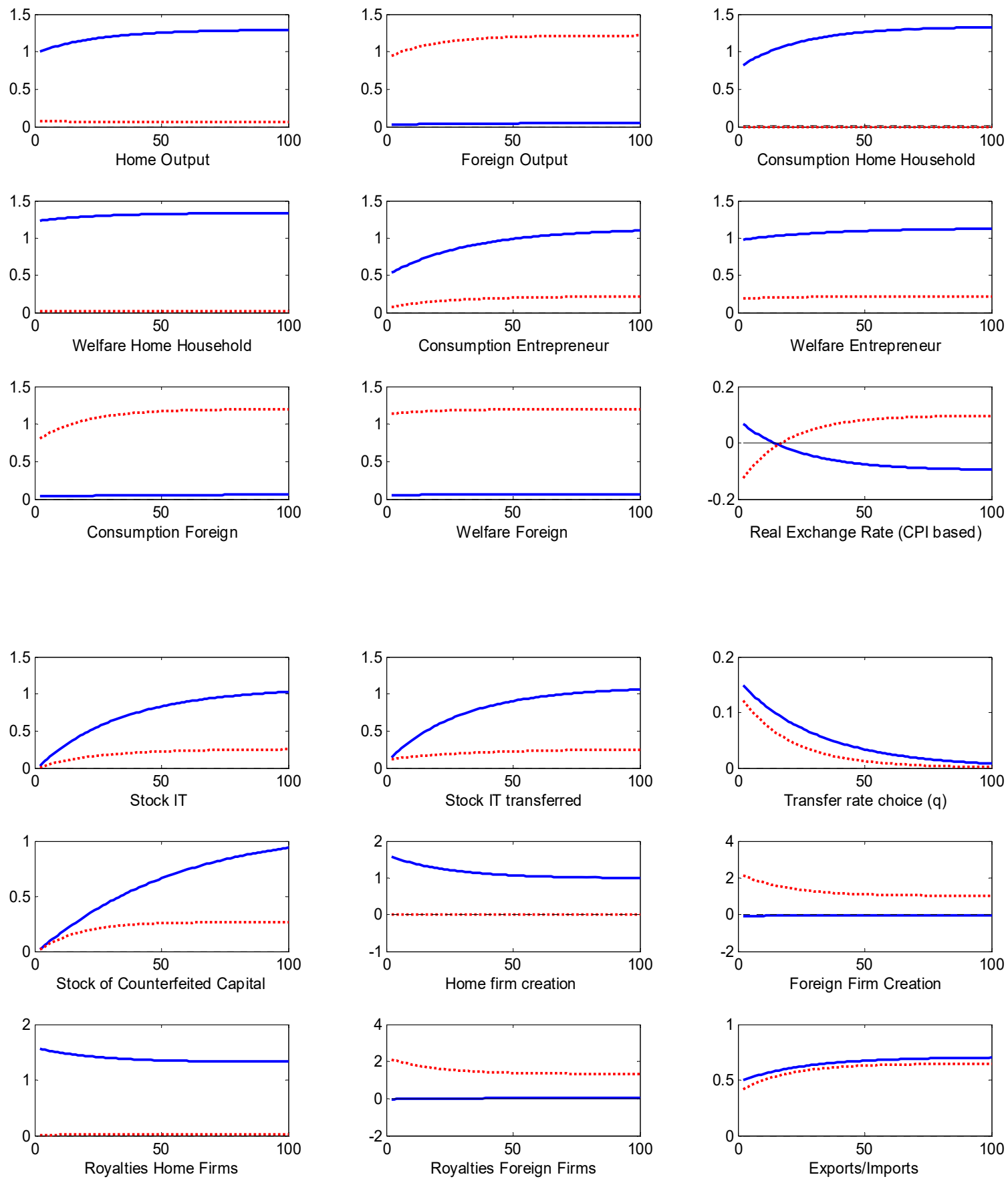

Note: Models' response to a permanent 1\% increase in productivity in Home (blue solid) and Foreign (red-dotted) 


\section{Data Appendix}

We supplement our previous analysis by explicitly controlling for the R\&D intensity of the industry.

\begin{tabular}{|c|c|c|c|}
\hline Variable & $\begin{array}{c}(1) \\
\ln (\text { Royalties) }\end{array}$ & $\begin{array}{c}(2) \\
\ln (\text { Royalties })\end{array}$ & $\begin{array}{c}(3) \\
\ln (\text { Royalties })\end{array}$ \\
\hline $\ln$ (Unaff Imports) & $\begin{array}{c}0.568^{* * * *} \\
(0.112)\end{array}$ & $\begin{array}{c}0.456^{* * *} \\
(0.124)\end{array}$ & $\begin{array}{c}0.387^{* * * *} \\
(0.137)\end{array}$ \\
\hline$\frac{R \& D}{\text { Sales }}$ & $\begin{array}{c}0.241^{* * *} \\
(0.061)\end{array}$ & $\begin{array}{l}0.205^{* * *} \\
(0.061)\end{array}$ & $\begin{array}{l}0.200^{* * * *} \\
(0.059)\end{array}$ \\
\hline $\ln ($ Parent Emp) & & $\begin{array}{l}0.630^{*} \\
(0.335)\end{array}$ & \\
\hline $\ln$ (Parent Sales) & & & $\begin{array}{l}0.585^{* *} \\
(0.286)\end{array}$ \\
\hline $\begin{array}{l}\text { Observations } \\
\text { R-squared }\end{array}$ & $\begin{array}{c}24 \\
0.738\end{array}$ & $\begin{array}{c}24 \\
0.776\end{array}$ & $\begin{array}{c}24 \\
0.776\end{array}$ \\
\hline
\end{tabular}

\section{Model Appendix}

\subsection{Model Equilibrium Conditions}

The equations below constitute a system of 46 equations in 46 endogenous variables:

$$
\begin{aligned}
& w, w^{*}, \tilde{d}, \tilde{d}^{*}, N_{E}, N_{E}^{*}, \tilde{\mathbf{z}}_{X}, \tilde{\mathbf{z}}_{X}^{*}, N_{D}, N_{D}^{*}, N_{X}, N_{X}^{*}, \tilde{v}, \tilde{v}^{*}, C_{h}, C^{*}, \mathbb{Q}, \tilde{\rho}_{D}, \tilde{\rho}_{D}^{*}, \tilde{\rho}_{X}, \tilde{\rho}_{X}^{*}, \tilde{d}_{D}, \tilde{d}_{D}^{*}, \tilde{d}_{X}, \\
& \tilde{d}_{X}^{*}, M, X, C_{e}, R, C, R^{*}, M^{*}, q, \lambda, \lambda^{*}, C_{\mathbf{a}}^{*}, C_{\mathbf{c}}^{*}, Y_{\mathbf{c}}^{*}, R_{\mathbf{c}}^{*}, M_{c}^{*}, y, y^{*}, Y_{t}^{*}, \Pi_{h, t}, \Pi_{e, t}, \Pi_{t}^{*} .
\end{aligned}
$$

Of these endogenous variables, five are predetermined at time $t: N_{D}, N_{D}^{*}, M, M^{*}, M_{c}^{*}$.

Additionally, the model features five exogenous variables: $\varepsilon_{t}^{i}$ with $i=\left\{\mathrm{Y}_{1} \mathrm{Y}^{*}, q, \mathrm{Z}, \mathrm{Z}^{*}\right\}$.

\subsection{Entrepreneurs}

Technology Capital Accumulation: 


$$
\begin{array}{lr}
M_{t}= & X_{t}+\left(1-\delta_{M}\right) M_{t-1} \\
M_{t}^{*}= & X_{t}+\left(1-\delta_{M}\right)\left(1-h\left(q_{t}\right)\right) M_{t-1}^{*}
\end{array}
$$

Budget Constraint

$$
C_{e, t}+X_{t}=R_{t} M_{t-1} N_{E, t}+Q_{t} q_{t} R_{t}^{*} M_{t-1}^{*} N_{E, t}^{*}+\Pi_{e, t}
$$

Optimality Conditions:

$$
\begin{aligned}
C_{e, t}^{-\gamma} & =\lambda_{t}+\lambda_{t}^{*} \\
\lambda_{t} & =\beta \mathbb{E}_{t}\left\{C_{e, t+1}^{-\gamma}\left(R_{t+1} N_{E, t+1}\right)+\lambda_{t+1}\left(1-\delta_{M}\right)\right\} \\
\lambda_{t}^{*} & =\beta \mathbb{E}_{t}\left\{C_{e, t+1}^{-\gamma}\left(Q_{t+1} q_{t+1} R_{t+1}^{*} N_{E, t+1}^{*}\right)+\lambda_{t+1}^{*}\left(1-\delta_{M}\right)\left(1-h\left(q_{t+1}\right)\right)\right\} \\
C_{e, t}^{-\gamma}\left(Q_{t} M_{t-1}^{*} R_{t}^{*} N_{E, t}^{*}\right) & =\lambda_{t}^{*}\left(1-\delta_{K}\right) M_{t-1}^{*} h^{\prime}\left(q_{t}\right) \\
\text { where } h\left(q_{t}\right) & =\varepsilon_{t}^{q}\left(\varepsilon_{t}^{Y^{*}}\right)^{\phi^{*}}\left[q_{t} \exp \left(-\eta\left(1-q_{t}\right)\right)\right], \text { and } h^{\prime}\left(q_{t}\right)=\varepsilon_{t}^{q}\left(\varepsilon_{t}^{Y^{*}}\right)^{\phi^{*}}\left(1+\eta q_{t}\right) \exp \left(-\eta\left(1-q_{t}\right)\right)
\end{aligned}
$$

\subsection{Firm Owners}

Evolution Number of Firms:

$$
\begin{array}{ll}
N_{D, t}= & (1-\delta)\left(N_{D, t-1}+N_{E, t-1}\right) \\
N_{D, t}^{*}= & (1-\delta)\left(N_{D, t-1}^{*}+N_{E, t-1}^{*}\right)
\end{array}
$$

Budget Constraints: 


$$
\begin{array}{lr}
N_{E, t} \tilde{v}_{t}+C_{h, t}= & w_{t} L+N_{D, t} \tilde{d}_{t}+\Pi_{h, t} \\
\tilde{v}_{t}^{*} N_{E, t}^{*}+C_{\mathbf{a}, t}^{*}= & w_{t}^{*} L^{*}+w_{\mathbf{c}, t}^{*} L_{\mathbf{c}}^{*}+R_{\mathbf{c}, t}^{*} M_{\mathbf{c}, t-1}^{*}+N_{D, t}^{*} \tilde{d}_{t}^{*}+\Pi_{t}^{*}
\end{array}
$$

Optimality Conditions:

$$
\begin{array}{ll}
\tilde{v}_{t}= & \beta(1-\delta) \mathbb{E}_{t}\left[\left(\frac{C_{h, t+1}}{C_{h, t}}\right)^{-\gamma}\left(\tilde{d}_{t+1}+\tilde{v}_{t+1}\right)\right] \\
\tilde{v}_{t}^{*}= & \beta(1-\delta) \mathbb{E}_{t}\left[\left(\frac{C_{\mathbf{a}, t+1}^{*}}{C_{\mathbf{a}, t}^{*}}\right)^{-\gamma}\left(\tilde{d}_{t+1}^{*}+\tilde{v}_{t+1}^{*}\right)\right]
\end{array}
$$

\subsection{Firms}

\section{Entry Cost:}

$$
\begin{aligned}
& R_{t} M_{t-1}=\quad f_{e} \frac{w_{t}}{Z_{t}} \text {, where } Z_{t}=\varepsilon_{t}^{Z} Z \\
& q_{t} R_{t}^{*} M_{t-1}^{*}=\quad f_{e}^{*} \frac{w_{t}^{*}}{Z_{t}^{*}} \text {, where } Z_{t}^{*}=\varepsilon_{t}^{Z^{*}} Z^{*}
\end{aligned}
$$

Free Entry Condition:

$$
\begin{array}{lr}
\tilde{v}_{t}= & R_{t} M_{t-1} \\
\tilde{v}_{t}= & q_{t} R_{t}^{*} M_{t-1}^{*}
\end{array}
$$

Domestic Prices:

$$
\begin{array}{ll}
\tilde{\rho}_{D, t}= & \frac{\theta}{(\theta-1)} \frac{w_{t}}{Z_{t} \mathbf{z}_{D}} \\
\tilde{\rho}_{D, t}^{*}= & \frac{\theta}{(\theta-1)} \frac{w_{t}^{*}}{Z_{t}^{*} \mathbf{z}_{D}^{*}}
\end{array}
$$


Export Prices:

$$
\begin{array}{ll}
\tilde{\rho}_{X, t}= & \mathbf{Q}_{t}^{-1}\left(1+\mathrm{Y}_{t}\right) \tau\left[\frac{\theta}{(\theta-1)} \frac{w_{t}}{Z_{t} \tilde{\mathbf{z}}_{X, t}}\right] \\
\tilde{\rho}_{X, t}^{*}= & \mathbf{Q}_{t}\left(1+Y_{t}^{*}\right) \tau^{*}\left[\frac{\theta}{(\theta-1)} \frac{w_{t}^{*}}{Z_{t} \tilde{\mathbf{z}}_{X, t}^{*}}\right]
\end{array}
$$

Dividends on Domestic Sales:

$$
\begin{array}{rr}
\tilde{d}_{D, t}= & \frac{1}{\theta}\left[\tilde{\rho}_{D, t}\right]^{1-\theta}\left(C_{h, t}+C_{e, t}\right) \\
\tilde{d}_{D, t}^{*}= & \frac{1}{\theta}\left[\tilde{\rho}_{D, t}^{*}\right]^{1-\theta} C_{t}^{*}
\end{array}
$$

Profits (Dividends) on Exports:

$$
\begin{aligned}
& \tilde{d}_{X, t}= \\
& \frac{Q_{t}}{\theta}\left[\tilde{\rho}_{X, t}\right]^{1-\theta} C_{t}^{*}-f_{X} \frac{w_{t}}{Z_{t}} \\
& \tilde{d}_{X, t}^{*}= \\
& \frac{1}{\mathrm{Q}_{t} \theta}\left[\tilde{\rho}_{X, t}^{*}\right]^{1-\theta}\left(C_{h, t}+C_{e, t}\right)-f_{X}^{*} \frac{w_{t}^{*}}{Z_{t}^{*}}
\end{aligned}
$$

Total Profits:

$$
\begin{array}{ll}
\tilde{d}_{t}= & \tilde{d}_{D, t}+\frac{N_{X, t}}{N_{D, t}} \tilde{d}_{X, t} \\
\tilde{d}_{t}^{*}= & \tilde{d}_{D, t}^{*}+\frac{N_{X, t}^{*}}{N_{D, t}^{*}} \tilde{d}_{X, t}^{*}
\end{array}
$$

Price Indexes for (licensed) Goods:

$$
\begin{array}{ll}
1= & N_{D, t}\left(\tilde{\rho}_{D, t}\right)^{1-\theta}+N_{X, t}^{*}\left(\tilde{\rho}_{X, t}^{*}\right)^{1-\theta} \\
1= & N_{D, t}^{*}\left(\tilde{\rho}_{D, t}^{*}\right)^{1-\theta}+N_{X, t}\left(\tilde{\rho}_{X, t}\right)^{1-\theta}
\end{array}
$$


Export Cutoffs

$$
\begin{array}{ll}
\tilde{d}_{X, t}= & f_{X} \frac{w_{t}}{Z_{t}} \frac{\theta}{k-(\theta-1)} \\
\tilde{d}_{X, t}^{*}= & f_{X}^{*} \frac{w_{t}^{*}}{Z_{t}^{*}} \frac{\theta}{k-(\theta-1)}
\end{array}
$$

Share of Exporting Firms

$$
\begin{array}{ll}
\frac{N_{X, t}}{N_{D, t}}= & \left(\mathbf{z}_{\min }\right)^{k}\left(\tilde{\mathbf{z}}_{X, t}\right)^{-k}\left[\frac{k}{k-(\theta-1)}\right]^{k /(\theta-1)} \\
\frac{N_{X, t}^{*}}{N_{D, t}^{*}}= & \left(\mathbf{z}_{\min }^{*}\right)^{k}\left(\tilde{\mathbf{z}}_{X, t}^{*}\right)^{-k}\left[\frac{k}{k-(\theta-1)}\right]^{k /(\theta-1)}
\end{array}
$$

\subsection{Additional Equations for Foreign}

Appropriated Capital:

$$
M_{\mathbf{c}, t}^{*}=\left(1-\delta_{K}^{*}\right) M_{\mathbf{c}, t-1}^{*}+h\left(q_{t}\right) M_{t-1}^{*}
$$

Consumption aggregators and relative prices/demand for licensed good and goods made using appropriated technology capital:

$$
\begin{array}{rr}
C_{\mathbf{a}, t}= & C_{t}^{*}+C_{\mathbf{c}, t}^{*} \\
C_{\mathbf{c}, t}^{*}= & Y_{\mathbf{c}, t}^{*}
\end{array}
$$

Production in the appropriating sector: 


$$
\begin{aligned}
Y_{\mathbf{c}, t}^{*}= & Z_{t}^{*} \tilde{\mathbf{z}}_{D}^{*} \Psi^{*}\left(M_{\mathbf{c}, t-1}^{*}\right)^{\alpha} \\
R_{\mathbf{c}, t}^{*} M_{\mathbf{c}, t-1}^{*}= & \alpha Y_{\mathbf{c}, t}^{*} \\
w_{\mathbf{c}, t}^{*}= & (1-\alpha) Y_{\mathbf{c}, t}^{*}
\end{aligned}
$$

\subsection{Value added, Tariffs, and Trade variables}

Balanced Trade:

$$
\frac{1}{\left(1+Y_{t}\right)} \mathbb{Q}_{t} N_{X, t}\left(\tilde{\rho}_{X, t}\right)^{1-\theta} C_{t}^{*}=\frac{1}{\left(1+Y_{t}^{*}\right)} N_{X, t}^{*}\left(\tilde{\rho}_{X, t}^{*}\right)^{1-\theta}\left(C_{h, t}+C_{e, t}\right)
$$

Tariffs:

$$
\begin{aligned}
\left(1+\mathrm{Y}_{t}^{*}\right)= & \varepsilon_{t}^{\mathrm{Y}^{*}}\left(\varepsilon_{t}^{q}\right)^{\phi}\left(1+\mathrm{Y}^{*}\right) \\
\left(1+\mathrm{Y}_{t}\right)= & \varepsilon_{t}^{\mathrm{Y}}(1+\mathrm{Y})
\end{aligned}
$$

Value Added:

$$
\begin{array}{rr}
y_{t}= & w_{t} L+N_{D, t} \tilde{d}_{D, t}+R_{t} M_{t-1} N_{E, t}+\mathbb{Q}_{t} q_{t} R_{t}^{*} M_{t-1}^{*} N_{E, t}^{*} \\
y_{t}^{*}= & w_{t}^{*} L^{*}+w_{\mathbf{c}, t}^{*} L_{\mathbf{c}}^{*}+N_{D, t}^{*} \tilde{d}_{t}^{*}+R_{\mathbf{c}, t}^{*} M_{\mathbf{c}, t-1}^{*}
\end{array}
$$

Lump-sum Transfers from Tariffs 


$$
\begin{aligned}
\Pi_{h, t}= & \frac{Y_{t}^{*}}{\left(1+Y_{t}^{*}\right)} N_{X, t}^{*}\left(\tilde{\rho}_{X, t}^{*}\right)^{1-\theta} C_{h, t} \\
\Pi_{e, t}= & \frac{Y_{t}^{*}}{\left(1+Y_{t}^{*}\right)} N_{X, t}^{*}\left(\tilde{\rho}_{X, t}^{*}\right)^{1-\theta} C_{e, t} \\
\Pi_{t}^{*}= & \frac{Y_{t}}{\left(1+Y_{t}\right)} N_{X, t}\left(\tilde{\rho}_{X, t}\right)^{1-\theta} C_{t}^{*}
\end{aligned}
$$

